\title{
Identification of zebrafish Fxyd11a protein that is highly expressed in ion-transporting epithelium of the gill and skin and its possible role in ion homeostasis
}

\author{
Kaori Saito ${ }^{\ddagger}$, Nobuhiro Nakamura ${ }^{\ddagger}$, Yusuke Ito, Kazuyuki Hoshijima ${ }^{\dagger}$, Masahiro Esaki, Boqiang Zhao and \\ Shigehisa Hirose*
}

Department of Biological Sciences, Tokyo Institute of Technology, Yokohama, Japan

\section{Edited by:}

David H. Evans, University of Florida, USA

\section{Reviewed by:}

Pung P. Hwang, Academia Sinica,

Taiwan

Greg G. Goss, University of Alberta, USA

\section{*Correspondence:}

Shigehisa Hirose, Department of

Biological Sciences, Tokyo Institute of Technology, 4259 B-19 Nagatsuta-cho, Midori-ku, Yokohama 226-8501, Japan e-mail: shirose@bio.titech.ac.jp

\section{${ }^{\dagger}$ Present address:}

Kazuyuki Hoshijima, Department of Human Genetics, University of Utah, 15N 2030E Salt Lake City, UT 84112, USA.

${ }^{\ddagger}$ Kaori Saito and Nobuhiro Nakamura have contributed equally to this work.
FXYD proteins, small single-transmembrane proteins, have been proposed to be auxiliary regulatory subunits of $\mathrm{Na}^{+}-\mathrm{K}^{+}-\mathrm{ATPase}$ and have recently been implied in ion osmoregulation of teleost fish. In freshwater (FW) fish, numerous ions are actively taken up through mitochondrionrich cells (MRCs) of the gill and skin epithelia, using the $\mathrm{Na}^{+}$electrochemical gradient generated by $\mathrm{Na}^{+}-\mathrm{K}^{+}-\mathrm{ATPase}$. In the present study, to understand the molecular mechanism for the regulation of $\mathrm{Na}^{+}-\mathrm{K}^{+}-A T P a s e$ in MRCs of FW fish, we sought to identify FXYD proteins expressed in MRCs of zebrafish. Reverse-transcriptase PCR studies of adult zebrafish tissues revealed that, out of eight $f x y d$ genes found in zebrafish database, only zebrafish fxyd11 (zfxyd11) mRNA exhibited a gill-specific expression. Double immunofluorescence staining showed that zFxyd11 is abundantly expressed in MRCs rich in $\mathrm{Na}^{+}-\mathrm{K}^{+}-$ATPase (NaK-MRCs) but not in those rich in vacuolar-type $\mathrm{H}^{+}$-transporting ATPase. An in situ proximity ligation assay demonstrated its close association with $\mathrm{Na}^{+}-\mathrm{K}^{+}-$ATPase in NaK-MRCs. The zfxyd11 mRNA expression was detectable at 1 day postfertilization, and its expression levels in the whole larvae and adult gills were regulated in response to changes in environmental ionic concentrations. Furthermore, knockdown of zFxyd11 resulted in a significant increase in the number of $\mathrm{Na}^{+}-\mathrm{K}^{+}-\mathrm{ATPase}$-positive cells in the larval skin. These results suggest that zFxyd11 may regulate the transport ability of NaK-MRCs by modulating $\mathrm{Na}^{+}-\mathrm{K}^{+}-\mathrm{ATPase}$ activity, and may be involved in the regulation of body fluid and electrolyte homeostasis.

Keywords: calcium, Danio renio, FXYD-domain ion transport regulator, mitochondria-rich cell, $\mathrm{Na}^{+}-\mathrm{K}^{+}$-ATPase, osmoregulation, salinity, teleost

\section{INTRODUCTION}

$\mathrm{Na}^{+}-\mathrm{K}^{+}$-ATPase is an energy transducing ion pump that couples ATP hydrolysis to the active transport of $3 \mathrm{Na}^{+}$ions out of and $2 \mathrm{~K}^{+}$ ions into the cell. $\mathrm{Na}^{+}-\mathrm{K}^{+}$-ATPase generates the electrochemical gradient for $\mathrm{Na}^{+}$and $\mathrm{K}^{+}$ions across the plasma membrane that is required for maintaining cell volume, membrane potential, and $\mathrm{pH}$ homeostasis in excitable and non-excitable cells. In the epithelia of the renal tubules and gut, the $\mathrm{Na}^{+}$gradient generated by $\mathrm{Na}^{+}-\mathrm{K}^{+}$-ATPase drives various ion and nutrient transporters, accomplishing ion- and osmoregulation and nutrient uptake. $\mathrm{Na}^{+}-\mathrm{K}^{+}$-ATPase functions as a hetero-oligomer of a large catalytic $\alpha$ subunit $(\sim 110 \mathrm{kDa})$ and a heavily glycosylated $\beta$ subunit $(\sim 55 \mathrm{kDa})$. The pump activity of the $\alpha$ subunit is tightly regulated by various factors, such as intracellular $\mathrm{Na}^{+}$concentration and phosphorylation which is under hormonal control (Therien and Blostein, 2000; Feraille and Doucet, 2001). The $\beta$ subunit has important roles in maturation, stability, and trafficking of $\mathrm{Na}^{+}-\mathrm{K}^{+}$-ATPase to the plasma membrane, as well as in $\mathrm{K}^{+}$binding (Geering, 2001; Shinoda et al., 2009). As an additional regulatory subunit, the FXYD-domain containing ion transport regulator (FXYD) family of small single-transmembrane proteins has been identified (Sweadner and Rael, 2000; Geering, 2006). FXYD proteins are characterized by a conserved Phe-X-Tyr-Asp motif at the cytoplasmic sides flanking their transmembrane domains. The transmembrane domain and the FXYD motif have been shown to play a role in binding to the $\alpha$ - and $\beta$-subunits (Béguin et al., 1997; Shinoda et al., 2009). FXYD proteins modulate $\mathrm{Na}^{+}-\mathrm{K}^{+}-$ ATPase activity by affecting the apparent affinities for intracellular $\mathrm{Na}^{+}$and extracellular $\mathrm{K}^{+}$ions (Béguin et al., 1997, 2001, 2002; Arystarkhova et al., 1999; Pu et al., 2001; Crambert et al., 2002, 2005; Garty et al., 2002; Geering, 2006; Delprat et al., 2007). In mammals, seven FXYD members (FXYD1-7) have been identified and shown to be expressed in a tissue-specific manner with distinct modulatory effects. The physiological roles of several FXYD proteins have been investigated by phenotypic analyses of knockout mice. FXYD1 (also known as phospholemman; PLM) is mainly expressed in heart, liver, and skeletal muscle, and its gene disruption leads to mild cardiac hypertrophy, increased ejection fraction, and a decrease in $\mathrm{Na}^{+}-\mathrm{K}^{+}$-ATPase activity and protein expression (Jia et al., 2005). Together with the fact that FXYD1 is physically and functionally associated with $\mathrm{Na}^{+} / \mathrm{Ca}^{2+}$ exchanger in myocytes (Zhang et al., 2003; Mirza et al., 2004), FXYD1 is likely involved in the regulation of cardiac contractility and intracellular $\mathrm{Ca}^{2+}$ concentration. Disruption of Fxyd2 (also known as $\gamma$ subunit), which is highly expressed in the kidney, causes an increase in affinities for $\mathrm{Na}^{+}$and ATP of renal $\mathrm{Na}^{+}-\mathrm{K}^{+}$-ATPase, but no obvious 
effect is seen on renal function (Jones et al., 2005). However, a mutation in the transmembrane domain of FXYD2 has been associated with renal hypomagnesemia (Meij et al., 2000; Pu et al., 2002). Knockout mice for Fxyd4 (also known as corticosteroid hormone-induced factor; CHIF), which is expressed in the distal nephron and colon, exhibit only mild renal impairment such as increased urine excretion and glomerular filtration rate during a high- $\mathrm{K}^{+}$or low- $\mathrm{Na}^{+}$diet (Aizman et al., 2002; Goldschimdt et al., 2004). Moreover, in the distal colon, $\mathrm{Na}^{+}$absorption is decreased even under normal conditions, suggesting the role of FXYD4 in electrolyte balance. Although less characterized than in mammals, some of orthologous and paralogous FXYD have been cloned from non-mammalian vertebrates, including spiny dogfish (Squalus acanthias) (Mahmmoud et al., 2000, 2003), Atlantic salmon (Salmo salar) (Tipsmark, 2008), and spotted green pufferfish (Tetraodon nigroviridis) (Wang et al., 2008). Recent studies have demonstrated that several teleost $f x y d$ isoforms are expressed in the gills and kidney and their expression levels are altered in response to ambient salinity changes, suggesting a possible role in the regulation of body fluid and electrolyte homeostasis (Tipsmark, 2008; Wang et al., 2008).

Fish living in freshwater (FW) are hyperosmotic to their environment $(\sim 300$ vs. $\sim 1 \mathrm{mOsm} / 1)$, and therefore constantly lose ions, mainly $\mathrm{Na}^{+}$and $\mathrm{Cl}^{-}$, and gain water. $\mathrm{FW}$ fish try to compensate this ionic and osmotic disturbance by active ion uptake through the gill and skin epithelium and excretion of dilute urine (Evans et al., 2005). In the gills and skin, mitochondrion-rich cells (MRCs, also called ionocytes or chloride cells) are the major sites of ion uptake, where $\mathrm{Na}^{+}-\mathrm{K}^{+}$-ATPase and numerous ion transporters are present (Marshall, 2002; Hirose et al., 2003; Perry et al., 2003; Kirschner, 2004; Evans et al., 2005; Hwang, 2009). $\mathrm{Na}^{+}-\mathrm{K}^{+}$-ATPase pumps $\mathrm{Na}^{+}$ ions out of MRCs across the basolateral membrane, maintaining a low intracellular $\mathrm{Na}^{+}$concentration. The $\mathrm{Na}^{+}$gradient across the apical membrane is proposed to provide the driving force for ion uptake. Although there is no doubt that $\mathrm{Na}^{+}-\mathrm{K}^{+}$-ATPase activity is essential for hypoosmotic adaptation of FW and euryhaline teleosts, a clear understanding as to how the activity in MRCs is regulated remains to be achieved. Recently, Wang et al. (2008) have provided evidence for FXYD-mediated regulation of $\mathrm{Na}^{+}-\mathrm{K}^{+}$-ATPase activity in MRCs of euryhaline teleost pufferfish, that is, (1) a pufferfish FXYD protein (pFXYD) is coincident and associated with $\mathrm{Na}^{+}-\mathrm{K}^{+}$-ATPase in the gill MRCs, and (2) the mRNA and protein expression levels of pFXYD are significantly increased after FW adaptation. In contrast, little is known about fxyd expression in MRCs of FW teleosts. It is therefore necessary to determine the identity and function of $f x y d$ isoforms expressed in FW fish MRCs in order to further understand the ion uptake mechanism by MRCs.

Zebrafish (Danio renio) is a stenohaline FW fish that can adapt to salinity changes in FW but not in seawater, and is increasingly recognized as a useful model organism for studies on the mechanism of ionic and osmotic homeostasis. The advantages of this model in studies are that (1) a combination of molecular and genetic approaches has been established, and (2) database of gene expression and genome information are currently available. Zebrafish has at least three types of MRCs in the skin and gill: MRCs rich in vacuolar-type $\mathrm{H}^{+}$-ATPase ( $\mathrm{vH}^{+}$-ATPase) (vH-MRCs or HR cells),
$\mathrm{Na}^{+}-\mathrm{K}^{+}$-ATPase (NaK-MRCs or $\mathrm{NaR}$ cells), or $\mathrm{Na}^{+}-\mathrm{Cl}^{-}$cotransporter (NCC cells) (Hwang, 2009). Multiple lines of evidence have demonstrated a primary role of $\mathrm{vH}-\mathrm{MRC}$ in $\mathrm{Na}^{+}$ion uptake through cooperation of $\mathrm{vH}^{+}$-ATPase, $\mathrm{Na}^{+} / \mathrm{H}^{+}$exchanger, and carbonic anhydrases (Lin et al., 2006, 2008; Esaki et al., 2007; Horng et al., 2007; Yan et al., 2007). On the other hand, the physiological roles of other two MRC subpopulations remain to be established, but $\mathrm{NaK}-\mathrm{MRC}$ and NCC cells are likely responsible for uptake of $\mathrm{Ca}^{2+}$ and $\mathrm{Cl}^{-}$ions, respectively (Pan et al., 2005; Liao et al., 2007; Wang et al., 2009). Most recently, Liao et al. (2009) have reported that each type of MRC expresses different $\mathrm{Na}^{+}-\mathrm{K}^{+}$-ATPase $\alpha$ isozymes in the zebrafish gill, mRNA expression levels of which are affected by environmental $\mathrm{Na}^{+}, \mathrm{Cl}^{-}$, and $\mathrm{Ca}^{2+}$ concentrations. Thus, it is conceivable that FXYD proteins may be expressed as a $\mathrm{Na}^{+}-\mathrm{K}^{+}$-ATPase regulator in the MRCs of FW fish. To address this issue, in this study, we sought to identify a FXYD protein(s) that is expressed in zebrafish MRCs. We demonstrated that zebrafish Fxyd11 (zFxyd11) is highly expressed in NaK-MRCs of the larval skin and gills, the expression levels of which are induced in low salinity environment. We further showed that zFxyd11 was associated with $\mathrm{Na}^{+}-\mathrm{K}^{+}$-ATPase in NaK-MRCs, and its knockdown affected the number of $\mathrm{Na}^{+}-\mathrm{K}^{+}-$ ATPase-positive cells of the larval skin. These results suggest that zFxyd11 is likely the regulator of $\mathrm{Na}^{+}-\mathrm{K}^{+}$-ATPase and involved in transepithelial ion transport across NaK-MRCs.

\section{MATERIALS AND METHODS ZEBRAFISH CULTURE}

Zebrafish were maintained as described in "The Zebrafish Book" (Westerfield, 1995). The wild-type zebrafish Tubingen long fin (TL) line was generously provided by Dr. Atsushi Kawakami (Yokohama, Japan). Unless otherwise mentioned, fertilized eggs were incubated at $28.5^{\circ} \mathrm{C}$ in $1 \times \mathrm{FW}$ [ $60 \mathrm{mg}$ ocean salt (Rohtomarine; Rei-sea, Tokyo, Japan) per 11 of distilled water, $\mathrm{pH}$ 7.7], which was used as our standard FW and corresponded to "Fish Water" (Westerfield, 1995). The concentration of major ions of $1 \times \mathrm{FW}$ are as follows: $\mathrm{Na}^{+}$, $686 \mu \mathrm{M} ; \mathrm{K}^{+}, 14.6 \mu \mathrm{M} ; \mathrm{Ca}^{2+}, 16.2 \mu \mathrm{M} ; \mathrm{Mg}^{2+}, 78.3 \mu \mathrm{M} ; \mathrm{Cl}^{-} 804 \mu \mathrm{M}$; $\mathrm{SO}_{4}^{-}, 41.6 \mu \mathrm{M}$; and $\mathrm{Br}^{-}, 1.25 \mu \mathrm{M}$. Hatched or dechorionated larvae were used for the following experiments without feeding. The animal protocols and procedures were approved by the Institutional Animal Care and Use Committee of Tokyo Institute of Technology.

\section{REVERSE-TRANSCRIPTASE POLYMERASE CHAIN REACTION (RT-PCR)}

Total RNA of whole larvae and various tissues of adult zebrafish was isolated as described previously (Tran et al., 2006; Nakada et al., 2007). For cDNA synthesis, $1 \mu \mathrm{g}$ of total RNA was reversetranscribed with oligo $(\mathrm{dT})_{20}$ primer and Superscript III reverse transcriptase (Invitrogen, Carlsbad, CA, USA). The resulting first strand cDNA $(0.5 \mu \mathrm{l})$ was used for PCR amplification in a reaction mixture containing $1.25 \mathrm{U}$ of ExTaq DNA polymerase (Takara, Shiga, Japan), $2.5 \mu$ of $10 \times$ ExTaq buffer (Takara), $0.2 \mathrm{mM}$ dNTP, and the following primer sets $(0.2 \mathrm{mM}$ each; listed in the order of forward and reverse): $z f x y d 2,5^{\prime}$-atgggagt ggaaagtcctgagcattcagat- $3^{\prime}$ and $5^{\prime}$-atcgtagcagaggactttccacatctgag $-3^{\prime} ; z f x y d 12,5^{\prime}$-atgtcaggagctcaggaggaagaggagcct- $3^{\prime}$ and $5^{\prime}$-atcga aatggcttcatccccatgcttgccc- $3^{\prime} ; z f x y d 5,5^{\prime}$-atgtcattcctcattccttatcaga tgacc- $3^{\prime}$ and $5^{\prime}$-atcgaacttctggtcacctcgtatgaactt- $3^{\prime} ;$ zfxyd6, $5^{\prime}$-atg 
gaaactgttctggtcttcctttttccc- $3^{\prime}$ and $5^{\prime}$-atccagttttctgctgtaggagtctcct $\operatorname{tg}-3^{\prime} ; z f x y d 8,5^{\prime}$-atggaactttgtgttgctgcagcgcttttg- $3^{\prime}$ and $5^{\prime}$-atctttgc acctctggctgcctctgcgtca- $3^{\prime} ; z f x y d 9,5^{\prime}$-atgaaatctttggcactagtgttcttga ca- $3^{\prime}$ and $5^{\prime}$-atcgagcattcactcgccctcgctgtgtcg- $3^{\prime} ; z f x y d 7,5^{\prime}$-atggaa gcctcaacagggtcatacacgcat $-3^{\prime}$ and $5^{\prime}$-atcgaaaaatacagcagtagatcagc attt- $3^{\prime}$; and $z f x y d 11,5^{\prime}$-atgagccagctcacagaactagttctccta- $3^{\prime}$ and $5^{\prime}$ -atcgagattttgcttgcgtcatcatcatgc- $3^{\prime}$. The Thermal cycler program was $3 \mathrm{~min}$ at $94^{\circ} \mathrm{C}$, followed by 25 cycles of $20 \mathrm{~s}$ at $94^{\circ} \mathrm{C}, 30 \mathrm{~s}$ at $58^{\circ} \mathrm{C}$, and $1 \mathrm{~min}$ at $72^{\circ} \mathrm{C}$. The PCR experiments were repeated twice (Figure 2A) or three times (Figures $1 \mathrm{~A}$ and $2 \mathrm{~B}, \mathrm{C}$ ) and representative results are shown.

\section{PLASMIDS}

The $z$ fxyd11 a cDNA fragment amplified with the above mentioned primer set was cloned into the EcoRV site of pBluescript II SK(-) (Stratagene, La Jolla, CA, USA), yielding pBS-zfxyd11a. By using pBS-zfxyd11 $a$ as template, primer-based site-directed mutagenesis was performed to introduce a stop codon at the end of the open reading frame of $z f x y d 11 a$ with primers $\left(5^{\prime}\right.$-acgcaagcaaaatctagatat cgaattcctg- $3^{\prime}$ and $5^{\prime}$-caggaattcgatatctagattttgcttgcgt- $3^{\prime}$ ). The XhoIXbaI-digested fragment of the mutated pBS-zfxyd11a was cloned into $\mathrm{pCS}^{+}$vector (RZPD German Resource Center for Genome Research, Berlin, Germany), yielding pCS2-zfxyd11a.AC-terminally $3 \times$ FLAG-tagged zFxyd11a (zFxyd11a-FLAG) was constructed by cloning the HindIII-EcoRV fragment of pBS-zfxyd11a into the same sites of p3× FLAGCMV14 (Sigma, St. Louis, MO, USA). An extracellularly $3 \times$ FLAG-tagged major histocompatibility complex (MHC) class I molecule was constructed by cloning a cDNA fragment encoding residues $25-365$ of HLA-A6802 into the EcoRI-XbaI site of the pSecTag-FLAG-furin vector (Nakamura et al., 2005). All constructs were verified by sequencing.

\section{SEMI-QUANTIFICATION OF GENE EXPRESSION LEVELS IN DIFFERENT SALINITY CONDITION BY RT-PCR}

In addition to $1 \times \mathrm{FW}$ as a routine medium, we prepared $1 / 5 \times \mathrm{FW}$ (12 mg ocean salt per liter) as a dilute FW medium and $20 \times \mathrm{FW}$ ( $1.2 \mathrm{~g}$ ocean salt per liter) and $160 \times \mathrm{FW}$ (9.6 g ocean salt per liter) as a concentrated medium. Adult zebrafish were cultured in $1 / 5 \times$ FW, $1 \times$ FW, $20 \times \mathrm{FW}$, and $160 \times \mathrm{FW}$ for 2 weeks, and the gills were then isolated. Total RNA of the gills was isolated and RT-PCR was performed as described above.

\section{IN SITUHYBRIDIZATION}

A cDNA encoding the open reading frame of zfxyd11a was subcloned into pGEMT-Easy vector (Promega, Medison, WI, USA) and was used for generation of digoxigenin (DIG)-labeled sense or antisense RNA probes. Paraffin-embedded sections of zebrafish gills (6- $\mu \mathrm{m}$ thickness) were de-paraffined with xylene, and rehydrated through an ethanol series and PBS. The sections were fixed $4 \%$ paraformaldehyde in PBS for 15 min and then washed with PBS. The sections were treated with $8 \mathrm{~g} / \mathrm{ml}$ proteinase $\mathrm{K}$ in PBS for 30 min at $37^{\circ} \mathrm{C}$, washed with PBS, re-fixed with $4 \%$ paraformaldehyde in PBS, again washed with PBS, and placed in $0.2 \mathrm{~N} \mathrm{HCl}$ for $10 \mathrm{~min}$. After washing with PBS, the sections were acetylated by incubation in $0.1 \mathrm{M}$ tri-ethanolamine- $\mathrm{HCl}, \mathrm{pH} 8.0,0.25 \%$ acetic anhydride for $10 \mathrm{~min}$. After washing with PBS, the sections were dehydrated through a series of ethanol. Hybridization was performed with probes at concentrations of $300 \mathrm{ng} / \mathrm{ml}$ in the Probe Diluent- 1 (Genostaff, Tokyo, Japan) at $60^{\circ} \mathrm{C}$ for $16 \mathrm{~h}$. The sections were washed in $5 \times$ HybriWash (Genostaff), equal to $5 \times$ SSC, at $60^{\circ} \mathrm{C}$ for $20 \mathrm{~min}$ and then in $50 \%$ formamide, $2 \times$ HybriWash at $60^{\circ} \mathrm{C}$ for $20 \mathrm{~min}$, followed by RNase treatment in $50 \mu \mathrm{g} / \mathrm{ml} \mathrm{RNaseA}$ in $10 \mathrm{mM}$ Tris- $\mathrm{HCl}, \mathrm{pH} 8.0,1 \mathrm{M} \mathrm{NaCl}$, and $1 \mathrm{mM}$ EDTA for $30 \mathrm{~min}$ at $37^{\circ} \mathrm{C}$. The sections were washed twice with $2 \times$ HybriWash at $60^{\circ} \mathrm{C}$ for $20 \mathrm{~min}$ and once with TBST (0.1\% Tween-20 in TBS). After treatment with $0.5 \%$ blocking reagent (Roche, Mannheim, Germany) in TBST for $30 \mathrm{~min}$, the sections were incubated with alkaline phosphatase-conjugated anti-DIG antibodies (diluted 1:1,000 with TBST) for $2 \mathrm{~h}$ at room temperature. The sections were washed twice with TBST and then incubated in $100 \mathrm{mM}$ $\mathrm{NaCl}, 50 \mathrm{mM} \mathrm{MgCl}, 0.1 \%$ Tween-20, $100 \mathrm{mM}$ Tris-HCl, $\mathrm{pH}$ 9.5. Coloring reactions were performed with NBT/BCIP solution (Sigma) overnight and then washed with PBS. The sections were counterstained with Kernechtrot stain solution (Muto Pure Chemicals, Tokyo, Japan), dehydrated, and then mounted with Malinol (Muto Pure Chemicals).

\section{ANTIBODIES}

Polyclonal antiserum specific for zFxyd 11 a was made in rabbits that had been immunized with a keyhole limpet hemocyanin (KLH)conjugated synthetic peptide corresponding to residues 53-69 of zFxyd11a (Operon Biotechnologies, Tokyo, Japan). Polyclonal antiserum specific for $\mathrm{vH}^{+}$-ATPase was made in rats that had been immunized with recombinant proteins of the $\mathrm{vH}^{+}$-ATPase $\beta$ subunit of dace (Tribolodon hakonensis) (Hirata et al., 2003).

\section{IMMUNOHISTOCHEMISTRY}

Immunostaining of larvae at 2 days postfertilization (dpf) were performed as described previously (Esaki et al., 2007), with exceptions that larvae were incubated two overnight at $4^{\circ} \mathrm{C}$ with rabbit anti-zFxyd 11 antiserum (diluted 1:2,000 with PBS containing 0.1\% Tween-20 and 10\% sheep serum), rat anti-eel (Anguilla japonica) $\alpha$-subunit of $\mathrm{Na}^{+}-\mathrm{K}^{+}$-ATPase antiserum (Miyamoto et al., 2002) (diluted 1:2,000), and rat anti-dace $\mathrm{vH}^{+}$-ATPase antiserum (diluted 1:1,000). Immunohistochemistry of gill sections was performed as described previously (Nakada, et al., 2007). After blocking with fetal bovine serum (FBS), the sections were incubated with antizFxyd11 (diluted 1:2,000) and anti-eel $\alpha$-subunit of $\mathrm{Na}^{+}-\mathrm{K}^{+}$-ATPase antisera (diluted 1:2,000) overnight at $4{ }^{\circ} \mathrm{C}$, followed by appropriate secondary antibodies for $1 \mathrm{~h}$ at room temperature. Hoechst $33342(100 \mathrm{ng} / \mathrm{ml}$; Invitrogen $)$ was added in the secondary antibody solutions for nuclei staining. Fluorescence images were acquired by using Axiovert 200M epifluorescence microscope (Carl Zeiss, Thornwood, NY, USA) equipped with an ApoTome optical sectioning device (Carl Zeiss).

\section{MORPHOLINO-MEDIATED KNOCKDOWN}

Morpholinos are chemically modified oligonucleotides that are more stable in, and less toxic to, living cells. An antisense morpholino oligonucleotide (MO) specific for $z f x y d 11$ (5'-ctcacagaac tagttctcctaacaggtaagtcaggattatttgtgtatac- $3^{\prime}$ ) was designed to complementarily anneal to the splicing donor site of the first exon of the $z f x y d 11$ transcript to block pre-mRNA splicing, and synthesized by Gene Tools (Philomath, OR, USA). For negative control 
experiments, Standard Control Oligo, Classic (Gene Tools) was used. Approximately $3 \mathrm{nl}$ of $1 \mathrm{ng} / \mathrm{nl}$ MOs in $1 \times$ Danieau buffer [58 mM NaCl, $0.7 \mathrm{mM} \mathrm{KCl}, 0.4 \mathrm{mM} \mathrm{MgSO}_{4}, 0.6 \mathrm{mM} \mathrm{Ca}\left(\mathrm{NO}_{3}\right)_{2}$, and $5 \mathrm{mM}$ HEPES, pH 7.6] was injected into the yolk of one-cell stage embryos, and then reared in $1 \times$ FW. The inhibitory action of MO was confirmed by RT-PCR; no doublet bands corresponding to $z f x y d 11 a$ and $z f x y d 11 b$ mRNA, which are typically seen in Figures 1 and 2, were amplified from total RNA preparations of MO-treated larvae (data not shown). For rescue experiments, the pCS2-zfxyd11 vector was linearized by NotI, and used as template to synthesize capped and polyadenylated $z f x y d 11$ a mRNA by using an SP6 RNA polymerase kit (Ambion, Austin, TX, USA). The synthesized $z$ fxyd $11 a$ mRNA was injected into cells at one-cell stage embryos at $30 \mathrm{pg} / \mathrm{nl}$ together with the $z$ fxyd11 MOs.

\section{IN SITUPROXIMITY LIGATION (PLA) ASSAY}

Gill sections were prepared as described above, and were blocked with $1 \%$ FBS in PBS for $1 \mathrm{~h}$ at room temperature. The sections were incubated with rabbit anti-zFxyd11 (diluted to $1: 1,000$ ) and rat anti-eel $\alpha$-subunit of $\mathrm{Na}^{+}-\mathrm{K}^{+}$-ATPase antisera (diluted $1: 1,000)$ for 2 days at room temperature, followed by corresponding secondary antibodies conjugated with the PLA oligonucleotide probes (PLA probe rabbit PLUS and PLA probe rat MINUS; Olink Bioscience, Uppsala, Sweden; diluted 1:5 with 1\% FBS in PBS) for $2 \mathrm{~h}$ at $37^{\circ} \mathrm{C}$. Hybridization and ligation of the connector oligonucleotides, a rolling-circle amplification, and detection of the amplified DNA products were performed with in situ PLA detection kit 613 (Olink Bioscience) according to the manufacturer's instruction. Following addition of $0.1 \% p$-prenylenediamine and $90 \%$ glycerol in PBS, the slides were covered with cover slips and photographed.

\section{CELL CULTURE AND TRANSFECTION}

Human embryonic kidney fibroblast 293T cells and human cervical HeLa cells were cultured in Dulbecco's Modified Eagle Medium containing 10\% FBS, $100 \mathrm{U} / \mathrm{ml}$ penicillin, and $100 \mu \mathrm{g} / \mathrm{ml}$ streptomycin at $37^{\circ} \mathrm{C}$ in a humidified atmosphere containing $5 \% \mathrm{CO}_{2}$. Transient transfection of plasmid DNA was performed using TransFectin reagent (Bio-Rad, Hercules, CA, USA) according to the manufacturer's instruction.

\section{MEMBRANE EXTRACTION ASSAY}

293T cells transfected with zFxyd11a-FLAG were homogenized in $600 \mu \mathrm{l}$ of PBS containing protease inhibitors (10 mM leupeptin, $1 \mathrm{mM}$ pepstatin, $5 \mathrm{mg} / \mathrm{ml}$ aprotinin, and $1 \mathrm{mM}$ phenylmethylsulfonyl fluoride). The homogenates were divided into four aliquots of $150 \mu \mathrm{l}$ each, and they were centrifuged at $100 \times \mathrm{g}$ for $20 \mathrm{~min}$ to separate the membranes from the cytosol. Extraction and fractionation of the membranes were performed as described previously (Nakamura and Hirose, 2008).

\section{IMMUNOFLUORESCENCE MICROSCOPY}

HeLa cells grown on cover slips were transfected with either $\mathrm{zFx}-$ yd11a-FLAG or FLAG-MHC-I. Immunofluorescence staining of transfected cells was performed as described previously (Nakamura et al., 2005) with exception that the permeabilization step was omitted to examine extracellular staining of the proteins.

\section{CELL-SURFACE BIOTINYLATION}

HeLa cells grown on a 6-well plate were transfected with zFxyd11a-FLAG. At 2 days after transfection, cell-surface proteins were biotinylated, extracted, and then purified with streptavidinagarose beads (Pierce, Rockford, IL, USA) as described previously (Nakamura et al., 1999).

\section{REAL-TIME PCR (qPCR)}

Total RNA used for qPCR was extracted independently of that used for RT-PCR from (i) twenty 5-dpf larvae adapted for 4 days to $1 / 20 \times$, $1 \times$, and $10 \times$ FW and (ii) gills from two adult zebrafish adapted for 3 days to $1 / 20 \times, 1 \times$, and $10 \times \mathrm{FW}$ by the acid guanidine isothiocyanatephenol-chloroform method with Isogen (Nippon Gene Co., Toyama, Japan). Synthesis of first strand cDNA and qPCR were performed as described previously (Hoshijima and Hirose, 2007). The primer sets used for qPCR were as follows (in the order of forward and reverse): fxyd11a, $5^{\prime}$-gccagctcacagaactagttctc- $3^{\prime}$ and $5^{\prime}$-aagcacacatgtgaagaccaaac- $3^{\prime}$; $\beta$-actin, $5^{\prime}$-tgttttcccctccattgttggac- $3^{\prime}$ and $5^{\prime}$-cgtgctcaatggggtatttgagg- $3^{\prime}$, which were designed to have $T_{m}$ of $59.7 / 59.0$ and $60.3 / 60.6^{\circ} \mathrm{C}$ and generate products of 125 and $134 \mathrm{bp}$, respectively.

\section{RESULTS}

\section{IDENTIFICATION OF A GILL-SPECIFIC ISOFORM OF ZEBRAFISH FXYD}

Through database searches, we found eight members of the zebrafish Fxyd (zFxyd) family ( $z f x y d 2, z f x y d 5, z f x y d 6, z f x y d 8, z f x y d 7$, $z f x y d 9, z f x y d 11$, and $z f x y d 12)$. To determine the tissue distribution of each $z f x y d$ isoform, we performed RT-PCR analysis by using RNA prepared from various tissues of adult zebrafish. We could detect amplified products for five out of eight $z f x y d$ genes $(z f x y d 7, z f x y d 8$, $z f x y d 9, z f x y d 11$, and $z f x y d 12$; Figure 1A). Among them, only $z f x y d 11$ was found to be specifically expressed in the gill. The $z f x y d 12$ message was detected in the liver and kidney, and other three members $(z f x y d 7, z f x y d 8$, and $z f x y d 9)$ showed broad expression patterns. We expected that $z f x y d 11$ has an important role in the gill function, in particular ion transport, and initiated its characterization.

\section{GENE STRUCTURE AND ALTERNATIVE SPLICING OF ZFXYD11}

In the RT-PCR assay, two $z f x y d 11$ cDNA fragments were amplified by using a single primer set (Figure 1A). Sequencing of the PCR products revealed that the short fragment ( $210 \mathrm{bp}$ ) encodes a 69-amino acid protein, termed here zFxyd11a, and the long one (338 bp) encodes a truncated zFxyd11a lacking eight C-terminal amino acids, termed here zFxyd11b (Figure 1B). Each nucleotide sequence was mapped back to the zebrafish genome by Blast search to identify the exon-intron structure of the $z f x y d 11$ gene. The $z f x$ $y d 11 b$ transcript consists of five coding exons whereas the $z f x y d 11 a$ is generated by a further alternative splicing within exon 6 (Figure 1C). This splicing follows the canonical GT-AG rule and the donor site is located just before the stop codon for the $z f x y d 11 b$ open reading flame (Figure 1D). The $z f x y d 11 a$ transcript thus acquires an 8 -amino acid C-terminal extension by skipping this stop codon.

\section{DEVELOPMENTAL STAGE- AND SALINITY-DEPENDENT EXPRESSION OF ZFXYD11 mRNA}

We examined expression of $z f x y d 11$ mRNA at different developmental stages from $12 \mathrm{~h}$ postfertilization (hpf) to 6-dpf. Total RNA of whole zebrafish embryos/larvae was extracted at each 


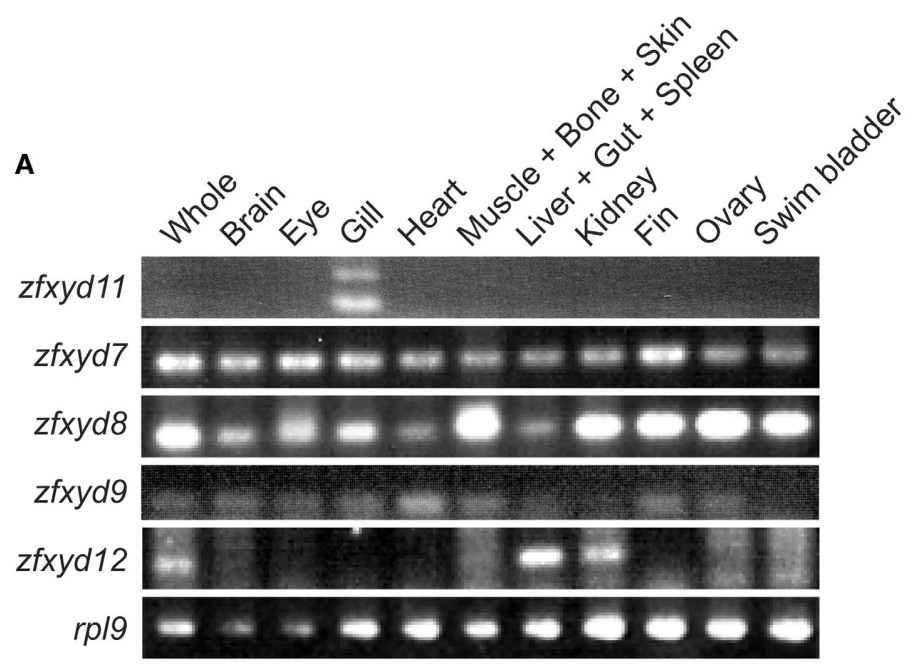

B

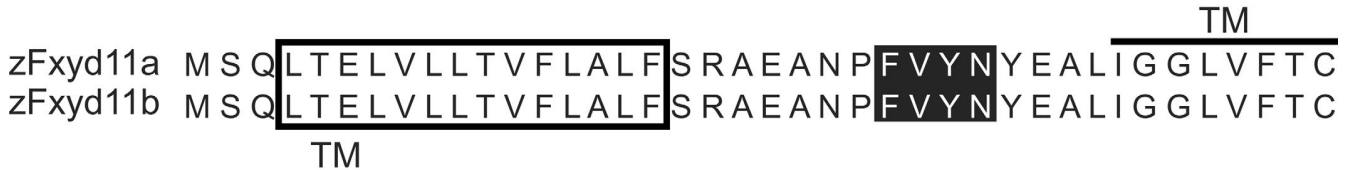

zFxyd11a VLVAGAVTALCW GQCKPKRKHDDDASKI zFxyd11b VLVAGAVTALCWGQCKPKRK

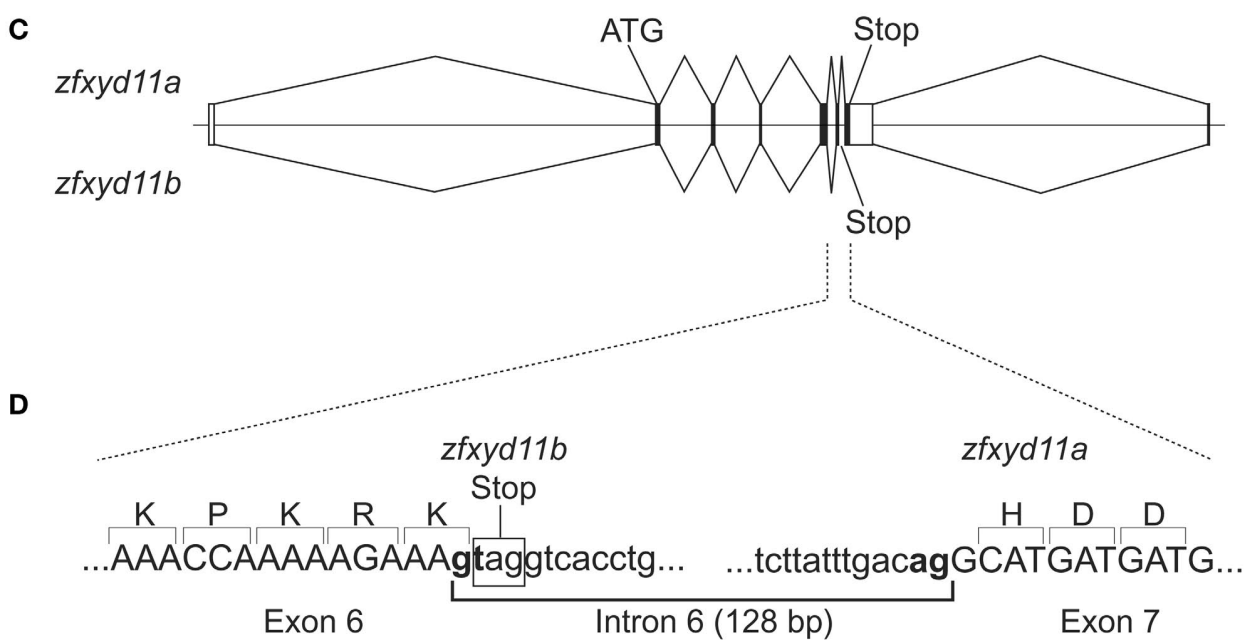

FIGURE 1 |Tissue expression pattern of zebrafish $f x y d$ isoforms and structure of zfxyd11 variants. (A) Total RNA isolated from various tissues of adult zebrafish were subjected to RT-PCR amplification by using specific primers for the indicated zebrafish fxyd isoforms and ribosomal protein L9 (rp/9). (B) Amino acid sequences of zFxyd11a and zFxyd11b. The putative signal sequences and the transmembrane (TM) domains are indicated by box and horizontal, respectively. The FXYD motifs are highlighted. (C) Schematic representation of alternative splicing of the zfxyd11 gene. Exons are indicated by boxes, and introns and flanking regions are indicated by horizontal lines. The coding and untranslated regions are indicated by dark and open boxes, respectively. $z F x y d 11 b$ is generated through alternative use of the stop codon in intron 6. (D) Exon-intron organization and boundary sequence of zfxyd11a. The splice donor and acceptor sequences are bold, and the stop codon of $z f x y d 11 b$ is indicated by the box. developmental stage and subjected to RT-PCR amplification with primers for $z f x y d 11$ and ribosomal protein L9 ( $r p l 9$, used as an internal control). As shown in Figure 2A, the $z f x y d 11$ expression was detectable at 1-dpf and all subsequent stages we examined. Since it has been shown that ambient ionic strength affects the expression levels of several teleost fxyd isoforms in salmon (Tipsmark,
2008) and pufferfish (Wang et al., 2008), we next examined whether zfxyd11 mRNA expression responds to environmental salinity. Zebrafish larvae were transferred from standard FW $(1 \times \mathrm{FW})$ to either fivefold diluted FW (1/5× FW) or 20- or 160-fold concentrated FW $(20 \times$ or $160 \times \mathrm{FW})$ at 24 -hpf and cultured for 6 days. As shown in Figure 2B, $z f x y d 11$ mRNA expression was increased in 


\section{A}
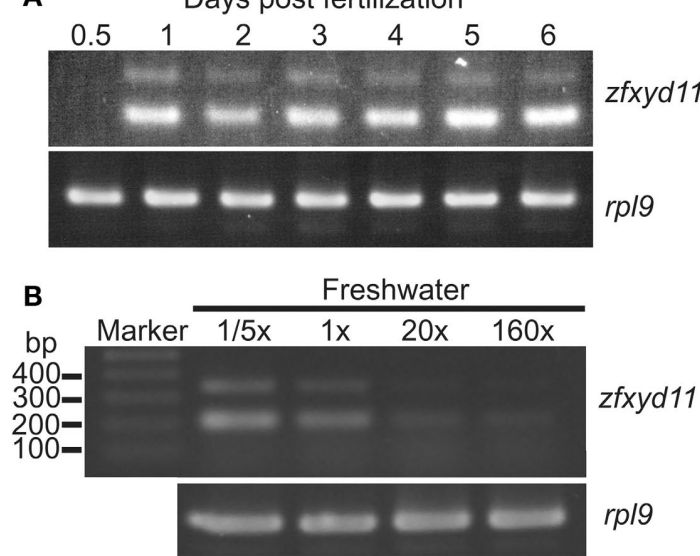

C

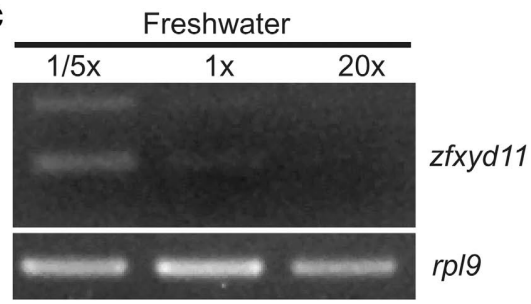

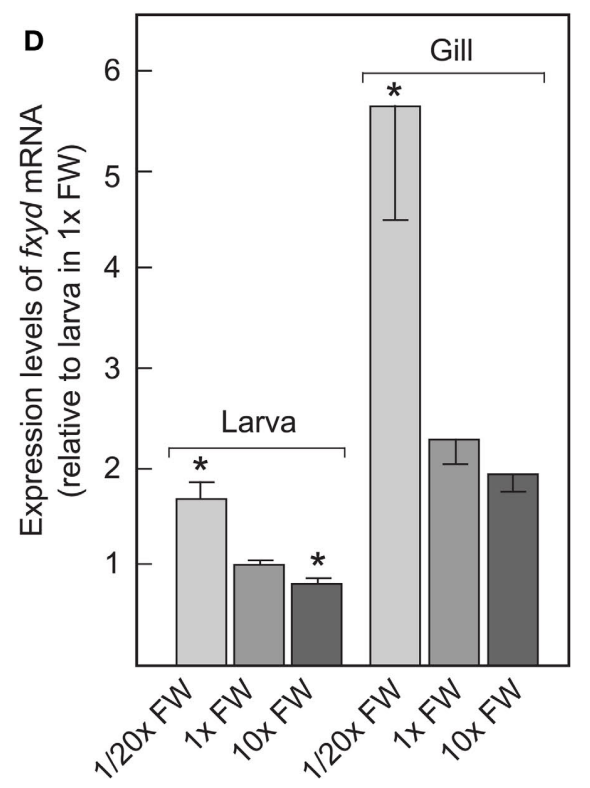

FIGURE 2 | Developmental stage- and ionic strength-dependent expression of zfxyd11 mRNA. (A) Expression of zfxyd11 at different developmental stages of zebrafish. RT-PCR was performed with total RNA isolated from the indicated stages of whole embryos/larvae. rp/9 was used as an internal control. (B) Expression of zfxyd11 and rp/9 was analyzed by RT-PCR with total RNA isolated from 7-dpf larvae acclimated to 1/5×, 1×, 20×, and 160× FW. Each acclimation was started at 1-dpf and extended to 7-dpf. (C) Expression of zfxyd11 and rp/9 was analyzed by RT-PCR with total RNA isolated from the gills of seven adult zebrafish acclimated to $1 / 5 \times, 1 \times$, and $20 \times$ FW for 2 weeks. (D) zfxyd11a mRNA expression in larvae and gills of zebrafish acclimated to the indicated salinity by quantitative RT-PCR (qPCR) ( $n=4)$. Data are expressed relative to the mRNA level of larvae acclimated to $1 \times \mathrm{FW} .{ }^{*} p<0.05$ in the comparison with $1 \times \mathrm{FW}$ (Student's $t$-test).
$1 / 5 \times \mathrm{FW}$-acclimated larvae whereas it was decreased under high salinity conditions. A similar effect was observed in the gill of adult zebrafish acclimated to $1 / 5 \times, 1 \times$, and $20 \times \mathrm{FW}$ for 2 weeks (Figure 2C). The salinity-dependent expression of $f x y d 11$ in larvae and gills was confirmed by real-time PCR (Figure 2D).

\section{EXPRESSION OF zFxyd11 IN NaK-MRCs}

To elucidate localization of $z f x y d 11$ mRNA at the cellular level, we carried out in situ hybridization on paraffin-embedded gill sections of adult zebrafish. Strong labeling was detected in the basal regions of the secondary lamellae with the antisense $z f x y d 11$ probe (Figure 3A). No such staining was observed in control experiments with the sense probe (Figure 3B). We also performed in situ hybridization using 1- to 7-dpf zebrafish larvae, but we could not detect any positive signal in either $1 \times \mathrm{FW}$ - or $1 / 5 \times \mathrm{FW}$-acclimated larvae (data not shown). Expression of $z f x y d 11$ in larvae was probably too low to detect under our experimental conditions. Since FXYD proteins are known to modulate $\mathrm{Na}^{+}-\mathrm{K}^{+}$-ATPase activity, we expected that zFxyd11 is expressed in the $\mathrm{Na}^{+}-\mathrm{K}^{+}$-ATPaserich MRCs in the gills. To examine this, we carried out immunohistochemical analysis of the gills by using rabbit polyclonal antiserum specific to the C-terminus of zFxyd11a. Gill sections of adult zebrafish were doubly stained with anti-zFxyd11 antiserum and anti- $\mathrm{Na}^{+}-\mathrm{K}^{+}$-ATPase antiserum (to stain NaK-MRCs). As expected, signals for $\mathrm{zFxyd} 11$ were detected on NaK-MRCs in the gill filaments (Figures 4A-E). No specific staining was observed with preimmune serum (Figure 4F), confirming the specificity of the antiserum. In contrast to our results of in situ hybridization, which failed to detect signals in the skin of larvae, we could detect zFxyd11 protein expression in 2-dpf zebrafish larvae by immunohistochemistry. The staining of zFxyd 11 was colocalized with that of $\mathrm{Na}^{+}-\mathrm{K}^{+}$-ATPase in the skin of the yolk sac, yolk sac extension, and trunk (Figure 5A and Figures S1A,B in Supplementary Material). When $z$ Fxyd11 was labeled with $\mathrm{vH}^{+}$-ATPase, a marker for vH-MRCs, two proteins were detected separately (Figure 5B and Figures S1C,D in Supplementary Material). No such zFxyd11 signal was observed with preimmune serum (Figures S1E,F in Supplementary Material). Therefore, these results indicate that zFxyd11 is expressed preferentially in NaK-MRCs of the gills and larval skin.

\section{INTERACTION OF zFxyd11 WITH NA+-K+'-ATPase IN THE GILLS}

To examine whether zFxyd 11 interacts with $\mathrm{Na}^{+}-\mathrm{K}^{+}$-ATPase, we performed the in situ proximity ligation assay (PLA) that enables to visualize endogenous protein-protein interactions at single molecular resolution (Söderberg et al., 2008). Cryosections of the gills of adult zebrafish were incubated with anti-zFxyd 11 and anti-Na ${ }^{+}-\mathrm{K}^{+}$-ATPase antisera followed by corresponding secondary antibodies conjugated with different oligonucleotides (PLA probes) that provide templates for two connector oligonucleotides. 


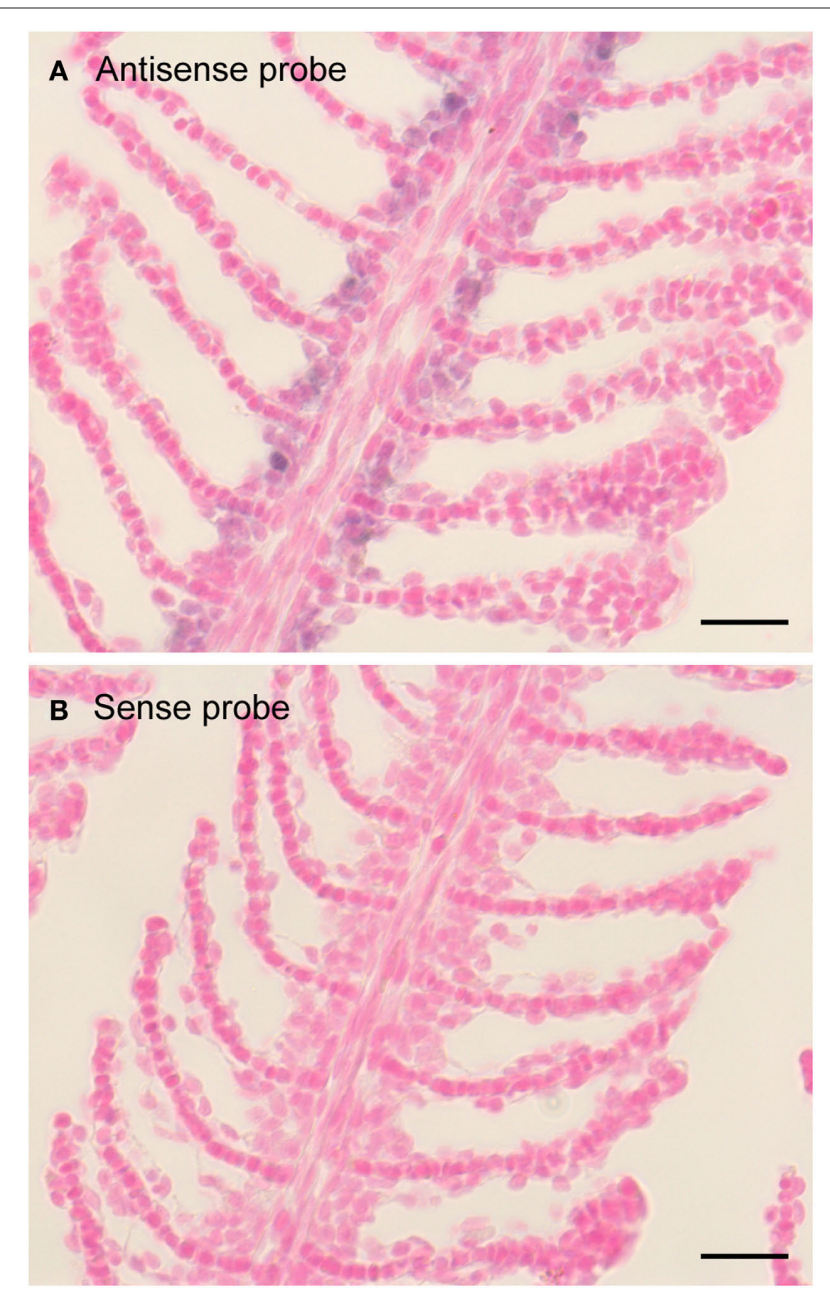

FIGURE 3 | Expression pattern of zfxyd11 mRNA in the gill of adult zebrafish. In situ hybridization was performed on paraffin-embedded gill sections of adult zebrafish with a DIG-labeled zfxyd11 antisense probe (A) or a sense probe as a control (B). Signals for zfxyd11 mRNA (violet) appeared to be abundant in the basal regions of the secondary lamellae. Scale bars, $10 \mu \mathrm{m}$.

Annealing and ligation of the connector oligonucleotides produced a circular single-stranded DNA molecule, which was then amplified by rolling-circle amplification to generate a long singlestrand DNA composed of tandem repeats of the DNA circle. The DNA products were visualized by hybridizing fluorescent-labeled oligonucleotide probes. As shown in Figure 6, a number of in situ PLA signals were detected on the gill lamellas with anti-zFxyd11 and anti- $\mathrm{Na}^{+}-\mathrm{K}^{+}$-ATPase antisera, while no signal was observed with preimmune serum instead of anti-zFxyd11 antiserum. The result suggests that zFxyd11 interacts with $\mathrm{Na}^{+}-\mathrm{K}^{+}$-ATPase in NaK-MRCs.

\section{EFFECTS ON ZFXYD11 KNOCKDOWN ON THE NUMBER OF NA+--K+- ATPase-POSITIVE CELLS}

To investigate the physiological functions of $\mathrm{zFxyd11}$, we performed $z$ fxyd11 knockdown experiments using morpholino antisense oligonucleotides (MOs) in zebrafish larvae. Control or $z f x y d 11$ MOs were injected into fertilized eggs at the one-cell stage, and the embryos were then allowed to develop to 2-dpf. Immunostaining of $z f x y d 11$ morphants showed no signal for zFxyd11, confirming $z f x y d 11$ knockdown at the protein level (Figure 7A). We analyzed the protein levels of $\mathrm{Na}^{+}-\mathrm{K}^{+}$-ATPase in NaK-MRCs by immunofluorescence microscopy. Average fluorescence intensity of labeled cells was similar between control and $z f x y d 11$ morphants. However, to our surprise, the number of $\mathrm{Na}^{+}-\mathrm{K}^{+}$-ATPase-positive cells apparently increased in the $z f x y d 11$ morphants compared with control larvae (compare Figure 7A and Figure 7B). Quantitative analysis revealed that the number of $\mathrm{Na}^{+}-\mathrm{K}^{+}$-ATPase-positive cells was significantly increased by $z f x y d 11$ knockdown [ $221 \pm 24.2$ vs. $153 \pm 28.7$ (control), $p<0.001$; Figure 7D]. The effect of $z f x y d 11$ knockdown was abrogated by co-injection with mRNA encoding zFxyd11a, and the number of NaK-MRCs was restored to control levels (Figures 7C,D) In contrast, the number of $\mathrm{vH}^{+}$ATPase-positive cells was not changed by $z$ fxyd11 knockdown (Figures 7E,F).

\section{MEMBRANE TOPOLOGY OF zFxyd11a}

zFxyd11a has two hydrophobic regions, corresponding to an $\mathrm{N}$-terminal signal sequence and a transmembrane span (see Figure 1B). zFxyd11a is thus predicted to be a type-I singletransmembrane protein (i.e., the protein has an $\mathrm{N}_{\text {out }}-\mathrm{C}_{\text {in }}$ orientation). To examine if zFxyd1la is an integral membrane protein, the membrane fractions were prepared from 293T cells transfected with a C-terminal FLAG-tagged zFxyd11a (zFxyd11a-FLAG) and were then incubated in PBS, $1 \mathrm{M} \mathrm{NaCl}, 0.1 \mathrm{M} \mathrm{Na}_{2} \mathrm{CO}_{3}(\mathrm{pH}$ 11.5), or $1 \%$ Triton X-100. After ultracentrifugation, the resulting supernatants and membrane pellets were analyzed by Western blotting with antibodies to FLAG, VTI1A [an integral membrane protein (Xu et al., 1998)], and dynamin-related protein 1 [DRP1, a cytosolic and peripheral membrane protein (Yoon et al., 1998)]. Under these conditions, zFxyd11a-FLAG could be solubilized effectively only in Triton X-100, an extraction profile similar to VTI1A (Figure 8A, top and middle panels). In contrast, DRP1 was released from the membranes by treatments with $1 \mathrm{M} \mathrm{NaCl}$ and $0.1 \mathrm{M} \mathrm{Na}_{2} \mathrm{CO}_{3}$ (Figure 8A, bottom panel). Next, to confirm the topology of zFxyd11a, we performed immunofluorescence microscopy of transfected HeLa cells. HeLa cells were transiently transfected with either zFxyd11a-FLAG or extracellularly FLAGtagged MHC class I (FLAG-MHC-I). The cells were then stained by using anti-FLAG antibody with or without Triton permeabilization. As shown in Figure $\mathbf{8 B}$, both proteins were stained with permeabilization whereas only FLAG-MHC-I was stained without permeabilization. To confirm cell-surface expression of zFxyd11a-FLAG in the transfected cells, cell-surface proteins were biotinylated, isolated by binding to streptavidin beads, and then subjected to Western blotting with anti-FLAG antibody. As shown in Figure 8C, the protein band corresponding to zFxyd11a-FLAG was detected in the biotinylated protein sample. These results suggest that zFxyd11a is an integral membrane protein extruding its C-terminal tail to the cytosol.

\section{DISCUSSION}

A number of studies have demonstrated that MRCs play a crucial role in ion and osmotic regulation in teleost FW fish (Marshall, 2002; Hirose et al., 2003; Perry et al., 2003; Kirschner, 2004; Evans et 

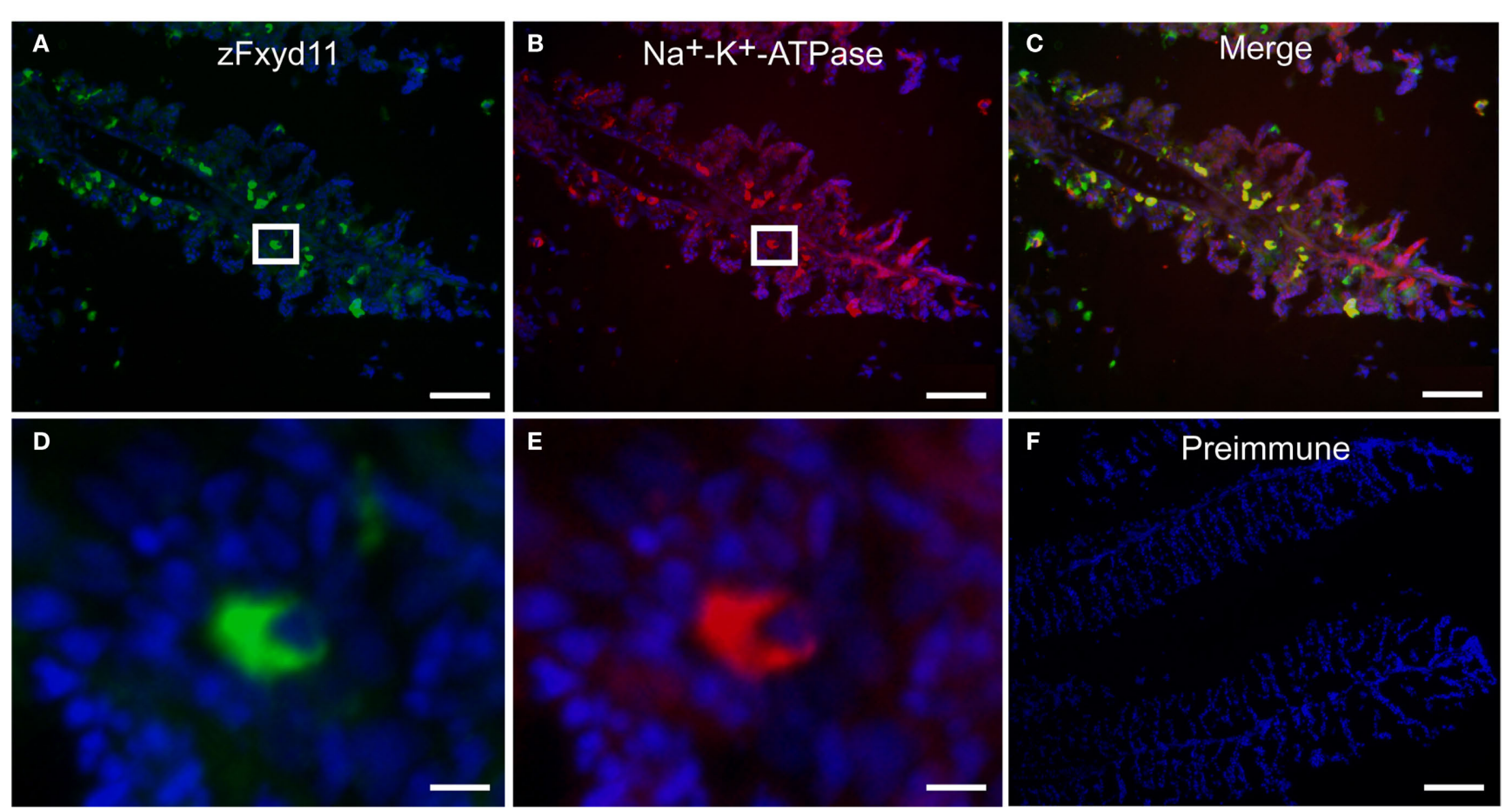

E

$\mathbf{F}$

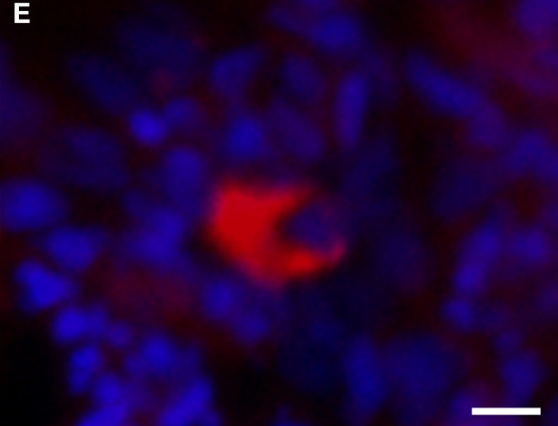

Preimmune

FIGURE 4 | Localization of zFxyd11 in NaK-MRCs of the gill of adult zebrafish. Immunofluorescence staining was performed on cryosections of the gill of adult zebrafish with anti-Na+-K+-ATPase antiserum [red in (B), (C), (E)] along with either anti-zFxyd11 antiserum [green in (A), (C), (D)] or with preimmune serum [green in (F)]. Nuclei were stained with Hoechst 33342 (blue). High magnification images of zFxyd11-positive cells in the boxed areas in $(\mathbf{A}, \mathbf{B})$ are shown in (D,E), respectively. Scale bars in $\mathbf{( A - C )}, 50 \mu \mathrm{m}$; in $(\mathbf{D}, \mathbf{E})$, $5 \mu \mathrm{m}$; in (F), $100 \mu \mathrm{m}$

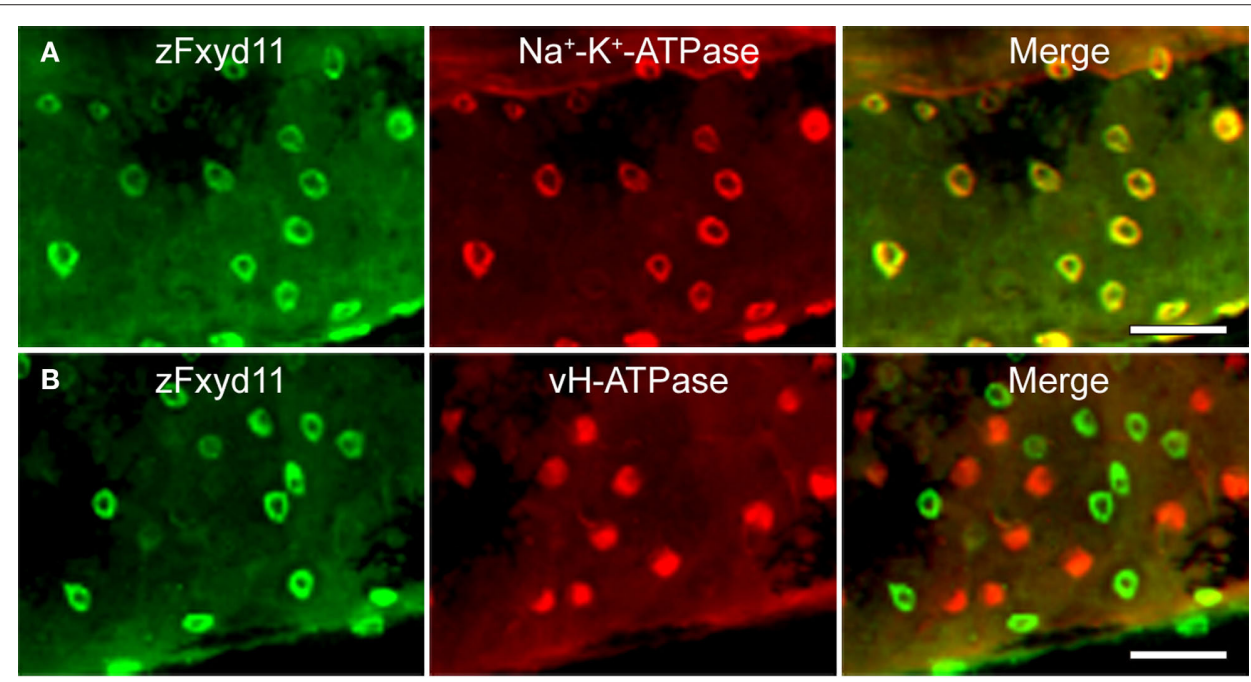

FIGURE 5 | Localization of zFxyd11 in NaK-MRCs of the skin of zebrafish larvae. Immunofluorescence staining was performed on 2-dpf zebrafish larvae with anti-zFxyd11 antiserum [green in (A), (B)], along with anti-Na+- $\mathrm{K}^{+}-\mathrm{ATPase}$ (red in (A)] or anti-vH $\mathrm{H}^{+}$-ATPase antiserum [red in (B)]. Regions of the yolk sac extension are shown. Note that signals for zFxyd11 entirely overlap with NaK-MRCs (A), and are not colocalized with vH-MRCs (B). Scale bars, $40 \mu \mathrm{m}$. al., 2005; Hwang, 2009). Although it is evident that active ion transport of MRCs as well as other ion-transporting epithelial cells is coupled to $\mathrm{Na}^{+}-\mathrm{K}^{+}$-ATPase, the regulatory mechanism of $\mathrm{Na}^{+}-\mathrm{K}^{+}$ATPase activity in MRCs remains to be clarified. Since the first fish FXYD was identified from shark rectal glands (Mahmmoud et al.,
2000), the presence of teleost FXYD has been detected in osmoregulatory organs such as gills, intestine, and kidney (Tipsmark, 2008; Wang et al., 2008). A recent study has identified a euryhaline pufferfish FXYD protein (pFXYD) highly expressed in the gill MRCs, and has suggested its role in adaptation to environmental salinity 


\section{A Anti-zFxyd11 \& anti-Na ${ }^{+}-\mathrm{K}^{+}-$ATPase}

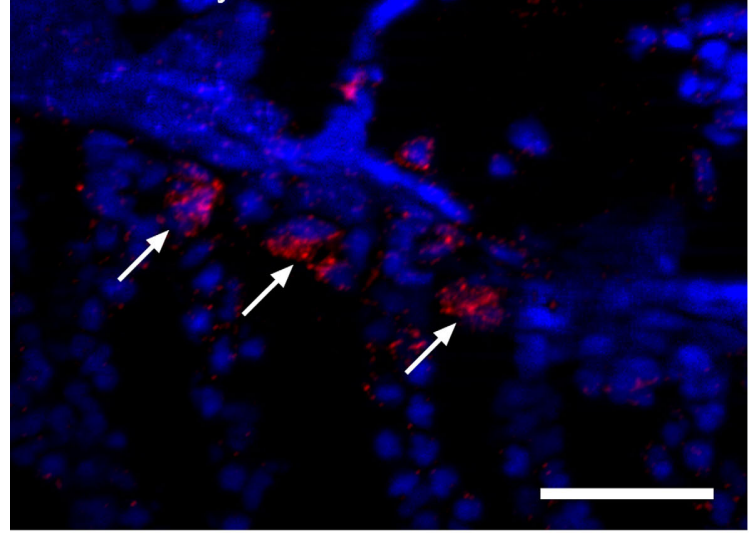

B Preimmune \& anti- $\mathrm{Na}^{+}-\mathrm{K}^{+}-\mathrm{ATPase}$

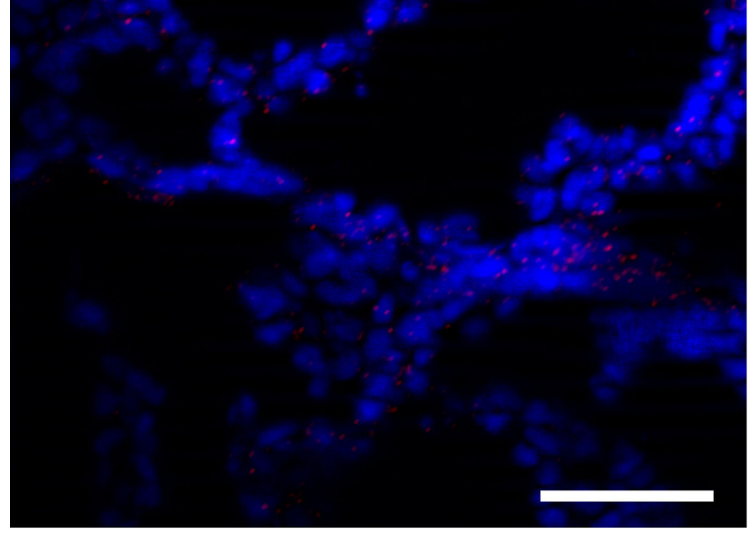

FIGURE 6 | Interaction between zFxyd11 and $\mathrm{Na}^{+}-\mathrm{K}^{+}-\mathrm{ATPase}$. In situ PLA was performed on cryosections of the gills of adult zebrafish with anti- $\mathrm{Na}^{+}-\mathrm{K}^{+}-$ ATPase antiserum along with either anti-zFxyd11 antiserum (A) or corresponding preimmune serum (B). Nuclei were stained with Hoechst 33342 (blue). Signals of interaction of two proteins were detected on the basal regions of the secondary lamellae (red, arrows). Scale bars, $25 \mu \mathrm{m}$.

changes (Wang et al., 2008). In the present study, we identified an additional FXYD that is likely to modulate $\mathrm{Na}^{+}-\mathrm{K}^{+}$-ATPase activity in the gill and skin MRCs of the FW fish zebrafish.

As reported by Tipsmark (2008), there are at least eight fxyd genes in the zebrafish database. Among them, we identified, by RT-PCR experiments using multiple tissue total RNA, $z$ f $x y d 11$ as a gill-specific isoform (Figure 1A). We confirmed $z$ f $x y d 11$ mRNA expression in the secondary gill lamella of adult zebrafish by in situ hybridization (Figure 3). Tipsmark (2008) has reported that Atlantic salmon $f x y d 11$, a homolog of $z f x y d 11$, also shows a gill-specific expression, suggesting that the fxyd11 isoform likely has a conserved function in the gills of teleost fish. Since expression of other $f x y d$ isoforms (i.e., $z f x y d 7, z f x y d 8$, and $z f x y d 9$ ) was detected in, but not restricted to, the gills (Figure 1A), we cannot exclude their possible involvement in the gill function. The RT-PCR experiments also revealed that the $z$ fxyd11 gene generates two variant transcripts, zfxyd11a and $z f x y d 11 b$, by alternative splicing, which differ in their C-terminal length (Figure 1B). Immunofluorescence microscopy and cell-surface biotinylation analyses demonstrated that zFxyd11a-FLAG was localized to the plasma membrane in mammalian cultured cells (Figures 8B,C). In addition, zFxyd11a-FLAG was found to be an integral membrane protein extruding its $\mathrm{C}$-terminal tail in the cytoplasm (Figures 8A,B), which is consistent with a typical membrane topology seen in mammalian FXYD proteins (Geering, 2006). zFxyd11b lacks the eight most C-terminal residues of zFxyd11a, and its $C$-terminal sequence matches the endoplasmic reticulum retention signal $(-\mathrm{K}-\mathrm{X}-\mathrm{K})$. It is possible that $\mathrm{zFxyd} 1 \mathrm{~b}$ might be localized to the endoplasmic reticulum, as is seen for mammalian FXYD1 (PLM), which has been shown to be retained in the endoplasmic reticulum by a $\mathrm{C}$-terminal -R-X-R motif in Madin-Darby canine kidney (MDCK) cells (Lansbery et al., 2006). A phylogenetic tree analysis indicated that $z$ Fxyd 11 is related to human FXYD3 and FXYD4 (Tipsmark, 2008), even though zFxyd11 shows distant sequence identities to them (32.2\% for FXYD3 and 26.6\% for FXYD4). Mammals have two FXYD3 splice isoforms with distinct modulatory roles: the short isoform decreases the apparent affinities for intracellular $\mathrm{Na}^{+}$and extracellular $\mathrm{K}^{+}$of $\mathrm{Na}^{+}-\mathrm{K}^{+}$-ATPase (Crambert et al., 2005; Bibert et al., 2006) whereas the long one decreases the apparent $\mathrm{K}^{+}$affinity in a voltage-dependent manner and increases the apparent $\mathrm{Na}^{+}$affinity (Bibert, et al., 2006). FXYD4 increases the apparent affinity for intracellular $\mathrm{Na}^{+}$of $\mathrm{Na}^{+}-\mathrm{K}^{+}-$ ATPase (Béguin et al., 2001; Garty et al., 2002). The low homology and the diverse properties of the mammalian FXYD proteins make it difficult to predict the functional role of zFxyd11 in the regulation of $\mathrm{Na}^{+}-\mathrm{K}^{+}$-ATPase activity. We tried to determine the effect of zFxyd11 knockdown on the activity of $\mathrm{Na}^{+}-\mathrm{K}^{+}$-ATPase by using anthroylouabain, a fluorescence dye of ouabain, which has been used to detect the $\mathrm{Na}^{+}-\mathrm{K}^{+}$-ATPase activity in intact MRCs of tilapia (McCormick, 1990), but such an approach is so far unsuccessful in zebrafish larvae. The exact effect of zFxyd11 interaction on the kinetics of $\mathrm{Na}^{+}-\mathrm{K}^{+}$-ATPase activity should be elucidated in future investigations.

Immunohistochemical analyses by using a specific polyclonal antibody revealed that zFxyd 11 is abundantly expressed in NaK-MRCs of the larval skin and the adult gills (Figures 4 and 5, and Figure S1 in Supplementary Material). Moreover, by using in situ PLA assay, we demonstrated a physical association between zFxyd 11 and $\mathrm{Na}^{+}-\mathrm{K}^{+}$-ATPase $\alpha$ subunit in NaK-MRCs (Figure 6). Taking into account the recent report by Wang et al. (2009) that the NCC cells, the third population of MRCs, are not stained with anti- $\mathrm{Na}^{+}-\mathrm{K}^{+}$-ATPase antibody, zFxyd 11 is unlikely to be highly expressed in NCC cells as in the case of vH-MRCs. The abundance of zFxyd 11 reasonably reflects the high expression and activity of $\mathrm{Na}^{+}-\mathrm{K}^{+}$-ATPase in $\mathrm{NaK}-\mathrm{MRCs}$. The gill and skin NaK-MRCs have been proposed to be responsible for active $\mathrm{Ca}^{2+}$ uptake via a set of $\mathrm{Ca}^{2+}$ channels and transporters to maintain calcium homeostasis (Pan et al., 2005; Craig et al., 2007; Liao et al., 2007, 2009; Tseng et al., 2009). The current model of transepithelial $\mathrm{Ca}^{2+}$ transport in mammalian kidney involves apical $\mathrm{Ca}^{2+}$ entry via epithelial $\mathrm{Ca}^{2+}$ channels (TRPV5 and TRPV6, also known as $\mathrm{ECaC} 1$ and $\mathrm{ECaC} 2$, respectively) and basolateral exit mediated by an $\mathrm{Na}^{+} / \mathrm{Ca}^{2+}$ exchanger (NCX1) and a $\mathrm{Ca}^{2+}$-ATPase (PMCA1b) (Hoenderop et al., 2005). By analogy to this model, the following mechanism for $\mathrm{Ca}^{2+}$ uptake at zebrafish gills is 

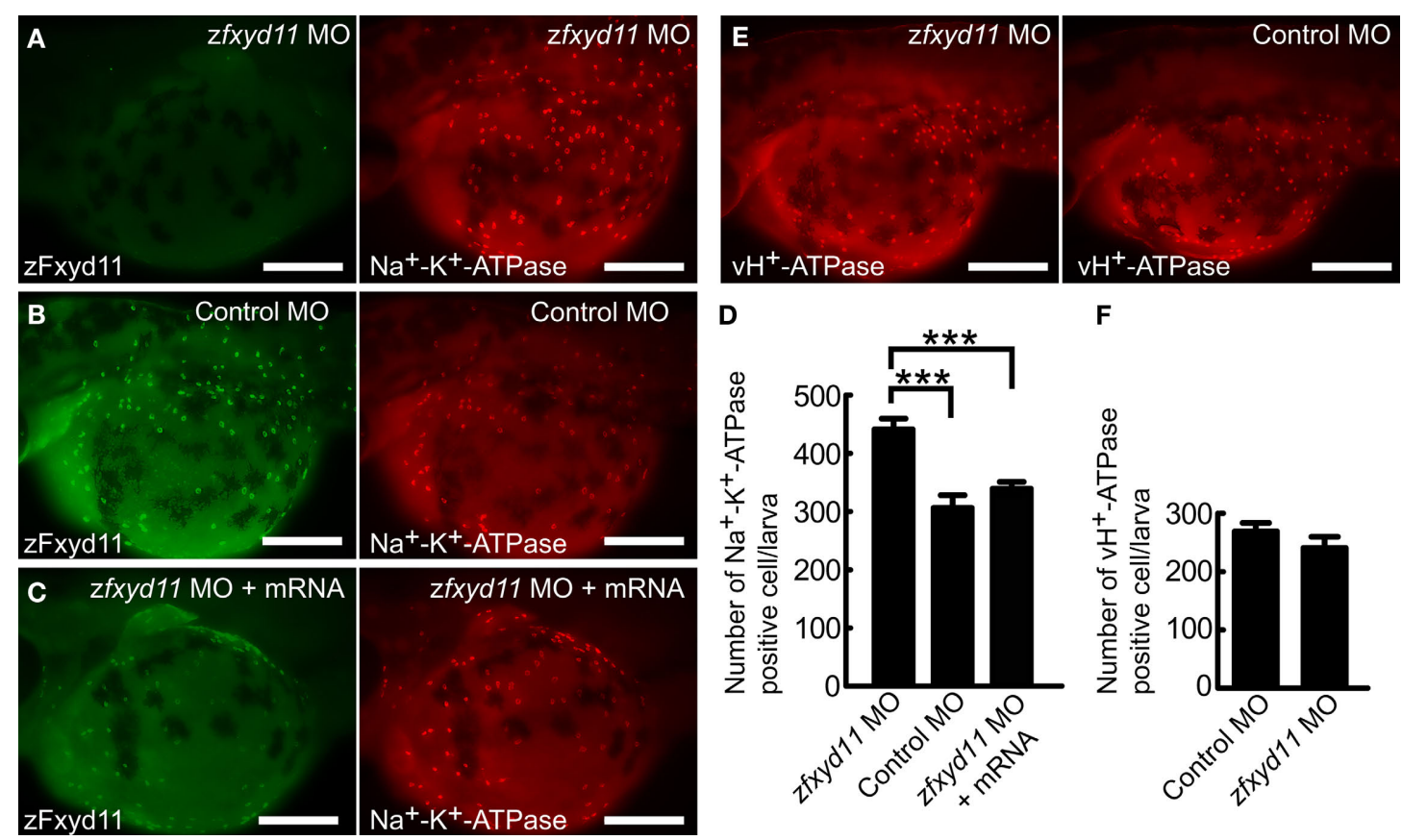

$\mathbf{F}$

FIGURE 7 | Effects of zFxyd11 knockdown. (A-C) Immunofluorescence staining was performed on zfxyd11-MO-injected (A), control-MO-injected (B), and zfxyd11-MO with zfxyd11a mRNA-injected larvae (C) with anti-zFxyd11 antiserum (green), along with anti-Na+- $\mathrm{K}^{+}-$ATPase antiserum (red). No signal for zFxyd11 was detected in zfxyd11 morphants (A). (D) The number of $\mathrm{Na}^{+}-\mathrm{K}^{+}-\mathrm{ATPase}-$ positive cells in the skin was counted and is represented as the mean \pm SEM. Significant

differences were evaluated by one-way ANOVA, Tukey's multiple comparison test $\left({ }^{* *} p<0.001, n=7\right)$. (E) Immunofluorescence staining was performed on zfxyd11-MO-injected (left panel), control-MO-injected larvae (right panel) with anti-v $\mathrm{H}^{+}$-ATPase antiserum. (F) The number of $\mathrm{vH}^{+}$-ATPase-positive cells in the skin was counted and is represented as the mean \pm SEM. The number of $\mathrm{vH}^{+}$-ATPase-positive cells was not affected by zFxyd11 knockdown $(n=7)$.

postulated: environmental $\mathrm{Ca}^{2+}$ ions are absorbed into $\mathrm{NaK}$ MRCs through the apical $\mathrm{Ca}^{2+}$ channel zECaC (Pan et al., 2005) and extruded to the blood by basolateral $\mathrm{Na}^{+} / \mathrm{Ca}^{2+}$ exchanger (NCX1b) and/or $\mathrm{Ca}^{2+}$ pump (zPMCA2) (Liao et al., 2007). In this $\mathrm{Ca}^{2+}$ transporting pathway, $\mathrm{Na}^{+}-\mathrm{K}^{+}$-ATPase is implicated in generating a $\mathrm{Na}^{+}$gradient across basolateral membrane that drives the $\mathrm{Na}^{+} / \mathrm{Ca}^{2+}$ exchanger. It has been shown that the $\mathrm{Na}^{+}-\mathrm{K}^{+}$-ATPase $\alpha$-subunit isozyme zatpla1a.1 is specifically expressed in the gill MRCs and its expression, as well as zecacl zECaC expression, is upregulated by low environmental $\mathrm{Ca}^{2+}$ (Liao et al., 2009). We observed a salinity-dependent regulation of zfxyd11 mRNA levels in the whole larvae and adult gills, in which it was increased by low ionic strength (Figures 2B,D). Since $\mathrm{Ca}^{2+}$ ion concentration of the diluted FW we used was $3.2 \mu \mathrm{M}$, which is low enough to upregulate zecac and zatpla1a.1 expression, $z f x y d 11$ expression was likely affected in response to environmental $\mathrm{Ca}^{2+}$ levels. Our findings suggest that zFxyd11 may contribute to the regulation of the $\mathrm{Ca}^{2+}$ uptake pathway by modulating the transport properties of $\mathrm{Na}^{+}-\mathrm{K}^{+}$-ATPase. Pan et al. (2005) have investigated the developmental regulation of $\mathrm{Ca}^{2+}$ uptake in zebrafish and showed that $\mathrm{Ca}^{2+}$ influx begins to occur at 36-hpf and is greatly enhanced during the hatching period (48- to $72-\mathrm{dpf}$ ). They have also reported that zecac mRNA and $\mathrm{Na}^{+}-\mathrm{K}^{+}$-ATPase protein expression are first detectable at 24-hpf, and the number of zecac-expressing NaK-MRCs is gradually increased during development (Pan et al., 2005). These facts suggest that the $\mathrm{Ca}^{2+}$-transporting machinery is equipped in zebrafish embryos before hatching and its expression is controlled to meet the increased $\mathrm{Ca}^{2+}$ demand of development. In our RT-PCR experiments, $z f x y d 11$ expression was detected at 24-hpf and subsequent developmental stages, which closely resembles the case of zecac expression (Figure 2A). This would be additional supporting evidence for a possible role of zFxyd 11 in $\mathrm{Ca}^{2+}$ uptake. Perry and colleagues have demonstrated that the zebrafish Slc26 $\mathrm{Cl}^{-} / \mathrm{HCO}^{-}$exchangers are expressed in a subset of $\mathrm{NaK}-\mathrm{MRC}$ of the gill and larval skin, and their knockdown causes a reduction of $\mathrm{Cl}^{-}$uptake in zebrafish larvae (Bayaa et al., 2009; Perry et al., 2009). Thus, we cannot exclude the possibility that zFxyd11 might be involved in $\mathrm{Cl}^{-}$transport through NaK-MRCs.

Our interesting observation is that knockdown of zFxyd11 expression resulted in a significant increase in the number of $\mathrm{Na}^{+}-\mathrm{K}^{+}$-ATPase-positive cells in the larval skin (Figure 7). It has been reported that the number and density of the skin MRCs are affected by environmental ionic and $\mathrm{pH}$ conditions (Pan et al., 2005; Horng et al., 2009). In particular, cultivation of zebrafish embryos in low-Ca ${ }^{2+} \mathrm{FW}$ increases the zecac-positive cells in the yolk sac skin (Pan et al., 2005), suggesting that proliferation and differentiation of NaK-MRCs accompany early embryonic development. The mechanism for MRC formation has recently been investigated and the factors involved have been identified and characterized. Both NaK-MRCs and $\mathrm{vH}-\mathrm{MRCs}$ are derived from the same precursor cell in the epidermal epithelium, in which the Delta-Notch signaling pathway controls proliferation 


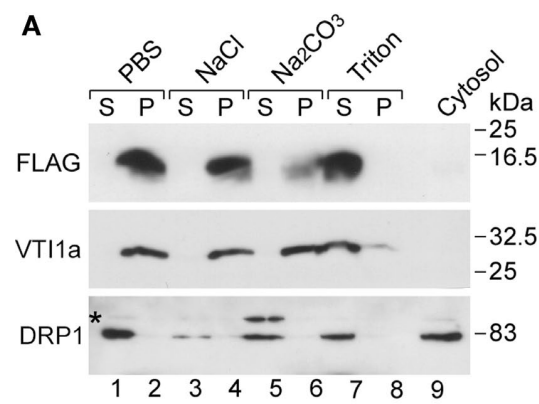

B $\quad$ - Triton $\mathrm{X}-100$

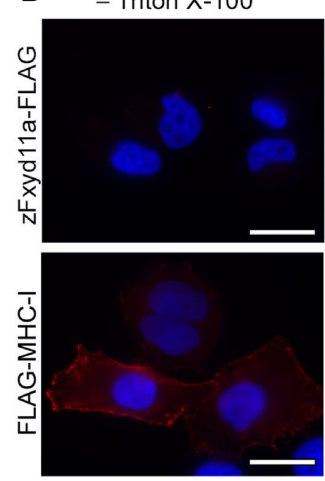

+ Triton X-100

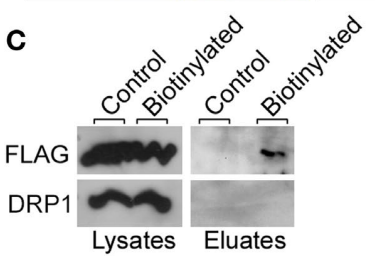

FIGURE 8 | Membrane topology of zFxyd11a. (A) Homogenates of 293T cells expressing zFxyd11a-FLAG were fractionated into the cytosolic (lane 9) and membranous fractions. The membranes were incubated with PBS (lanes 1 and 2), $1 \mathrm{M} \mathrm{NaCl}$ (lanes 3 and 4), $0.1 \mathrm{M} \mathrm{Na}_{2} \mathrm{CO}_{3}$ (pH 11.5, lanes 5 and 6), or $1 \%$ Triton X-100 (lanes 7 and 8) followed by ultracentrifugation to separate soluble protein supernatants (S; lanes 1, 3, 5, and 7) from membranous pellets ( $P$; lanes 2, 4, 6, and 8). The samples were analyzed by Western blotting with antibodies against FLAG, VTI1a (a TM protein), and DRP1 (a cytosolic protein) (B) HeLa cells were transfected with either zFxyd11a-FLAG (top panels) or FLAG-MHC-I (bottom panels) and were then processed for immunofluorescence staining with anti-FLAG antibody (red) without (left panels) or with (right panels) membrane permeabilization. Nuclei were stained with Hoechst 33342 (blue). Scale bars, $20 \mu \mathrm{m}$. (C) HeLa cells transfected with zFxyd11a-FLAG were lysed directly (Control) or were subjected to cell-surface biotinylation (Biotinylated). Whole cell lysates (left panels) and biotinylated samples (right panels) were analyzed by Western blotting with anti-FLAG antibody (top panels) and anti-DRP1 antibody (bottom panels).

\section{REFERENCES}

Aizman, R., Asher, C., Fuzesi, M., Latter, H., Lonai, P., Karlish, S. J., and Garty, H. (2002). Generation and phenotypic analysis of CHIF knockout mice. Am. J. Physiol. Renal. Physiol. 283, F569-F577.

Arystarkhova, E., Wetzel, R. K., Asinovski, N. K., and Sweadner, K. J. (1999). The gamma subunit modulates $\mathrm{Na}^{+}$and $\mathrm{K}^{+}$affinity of the renal Na,K-ATPase. J. Biol. Chem. 274, 33183-33185.

Bayaa, M., Vulesevic, B., Esbaugh, A., Braun, M., Ekker, M. E., Grosell, M., and Perry, S. F. (2009). The involvement of SLC26 anion transporters in chloride uptake in zebrafish (Danio rerio) larvae. J. Exp. Biol. 212, 3283-3295.

Béguin, P., Crambert, G., Guennoun, S., Garty, H., Horisberger, J. D., and

and distribution of MRC precursors, and the Foxi3a and Foxi3b transcription factors regulate following differentiation into individual MRCs (Hsiao et al., 2007; Jänicke et al., 2007; Esaki et al., 2009). After expression of foxi3a and foxi3b at 10-hpf, expression of atp $1 b 1 b$, a $\beta$-subunit of $\mathrm{Na}^{+}-\mathrm{K}^{+}$-ATPase, becomes detectable around 14-hpf (Hsiao et al., 2007). Thus, it seems likely that the ion-transporting machinery is expressed after cell proliferation and determination of cell specificity. Knockdown of zFxyd11 expression is unlikely to affect proliferation and differentiation of MRC precursors since its mRNA expression initiates between 12 and 24-hpf (Figure 2A). Hence, the following speculation could be put forward for the mechanism of the effects of zFxyd 11 knockdown: there is a subpopulation of MRCs expressing $\mathrm{Na}^{+}-\mathrm{K}^{+}-$ ATPase and zFxyd 11 at very low levels, and loss of zFxyd 11 causes a functional impairment of $\mathrm{Na}^{+}-\mathrm{K}^{+}$-ATPase and a subsequent decrease in ion-transporting ability of the cell, which leads to a feedback upregulation of $\mathrm{Na}^{+}-\mathrm{K}^{+}$-ATPase expression in the corresponding MRC population.

The localization, regulated expression, $\mathrm{Na}^{+}-\mathrm{K}^{+}$-ATPase interaction of zFxyd11 suggest its important role in zebrafish calcium homeostasis to allow proper development and to adapt changes of environmental ion concentrations. Other than NaK-MRCs, there are at least two populations of MRCs in zebrafish: vH-MRCs and NCC cells, which appear to be responsible for $\mathrm{Na}^{+}$and $\mathrm{Cl}^{-}$ions, respectively. It has been shown that $\mathrm{vH}-\mathrm{MRC}$ and NCC cells specifically express different $\mathrm{Na}^{+}-\mathrm{K}^{+}$-ATPase $\alpha$ isozymes, zatp1a1a.5 and zatp1a1a.2, respectively, which raises the possibility that their enzymatic activities are modulated by distinct FXYD proteins. Characterization of localization and functions of other FXYD isoforms would provide insight with regard to body fluid and electrolyte homeostasis in FW fish.

\section{ACKNOWLEDGMENTS}

We thank Dr. Atsushi Kawakami for providing the zebrafish TL line, Akira Kato, Taro Ichinose, and Tomoya Takahashi for their help in qPCR, Yoichi Noguchi and Kazuo Okubo of Genostaff for technical assistance in in situ hybridization histochemistry, and Keijiro Munakata, Tsutomu Nakada, Keiko Kawai, Noriko Isoyama, and Setsuko Sato for helpful suggestions and for technical and secretary assistance. This work was supported by Grant-in-Aid for Scientific Research (14104002, 18059010, 21026010, and 22370029) and for Young Scientists (20770156 and 22770123) and by the Global COE Programs of the Ministry of Education, Culture, Sports, Science and Technology of Japan.

Geering, K. (2001). CHIF, a member of the FXYD protein family, is a regulator of $\mathrm{Na}, \mathrm{K}$-ATPase distinct from the gamma-subunit. EMBO J. 20, 3993-4002.

Béguin, P., Crambert, G., MonnetTschudi, F., Uldry, M., Horisberger, J. D., Garty, H., and Geering, K. (2002). FXYD7 is a brain-specific regulator of $\mathrm{Na}, \mathrm{K}-\mathrm{ATP}$ ase alpha 1-beta isozymes. EMBO J. 21, 3264-3273.
Béguin, P., Wang, X., Firsov, D., Puoti, A., Claeys, D., Horisberger, J. D., and Geering, K. (1997). The gamma subunit is a specific component of the $\mathrm{Na}, \mathrm{K}$ ATPase and modulates its transport function. EMBO J. 16, 4250-4260.

Bibert, S., Roy, S., Schaer, D., Felley-Bosco, E., and Geering, K. (2006). Structural and functional properties of two human FXYD3 (Mat-8) isoforms. J. Biol. Chem. 281, 39142-39151. 
Craig, P.M., Wood, C. M., and McClelland, G. B. (2007). Gill membrane remodeling with soft-water acclimation in zebrafish (Danio rerio). Physiol. Genomics 30, 53-60.

Crambert, G., Fuzesi, M., Garty, H., Karlish, S., and Geering, K. (2002). Phospholemman (FXYD1) associates with $\mathrm{Na}, \mathrm{K}$-ATPase and regulates its transport properties. Proc. Natl. Acad. Sci. U.S.A. 99, 11476-11481.

Crambert, G., Li, C., Claeys, D., and Geering, K. (2005). FXYD3 (Mat-8), a new regulator of $\mathrm{Na}, \mathrm{K}$-ATPase. $\mathrm{Mol}$. Biol. Cell 16, 2363-2371.

Delprat, B., Schaer, D., Roy, S., Wang, J., Puel, J. L., and Geering, K. (2007). FXYD6 is a novel regulator of $\mathrm{Na}, \mathrm{K}$ ATPase expressed in the inner ear. $J$. Biol. Chem. 282, 7450-7456.

Esaki, M., Hoshijima, K., Kobayashi, S., Fukuda, H., Kawakami, K., and Hirose, S. (2007). Visualization in zebrafish larvae of $\mathrm{Na}^{+}$uptake in mitochondria-rich cells whose differentiation is dependent on foxi3a. Am. J. Physiol. Regul. Integr. Comp. Physiol. 292, R470-R480.

Esaki, M., Hoshijima, K., Nakamura, N., Munakata, K., Tanaka, M., Ookata, K., Asakawa, K., Kawakami, K., Wang, W., Weinberg, E. S., and Hirose, S. (2009). Mechanism of development of ionocytes rich in vacuolar-type $\mathrm{H}^{+}$-ATPase in the skin of zebrafish larvae. Dev. Biol. 329, 116-129.

Evans, D. H., Piermarini, P. M., and Choe, K. P. (2005). The multifunctional fish gill: dominant site of gas exchange, osmoregulation, acid-base regulation, and excretion of nitrogenous waste. Physiol. Rev. 85, 97-177.

Feraille,E., and Doucet,A.(2001).Sodiumpotassium-adenosinetriphosphatasedependent sodium transport in the kidney: hormonal control. Physiol. Rev. 81, 345-418.

Garty, H., Lindzen, M., Scanzano, R., Aizman, R., Fuzesi, M., Goldshleger, R., Farman, N., Blostein, R., and Karlish, S. J. (2002). A functional interaction between CHIF and Na-K-ATPase: implication for regulation by FXYD proteins. Am. J. Physiol. Renal. Physiol. 283, F607-F615.

Geering, K. (2001). The functional role of beta subunits in oligomeric P-type ATPases. J. Bioenerg. Biomembr. 33, 425-438.

Geering, K. (2006). FXYD proteins: new regulators of $\mathrm{Na}-\mathrm{K}-\mathrm{ATPase}$. Am. J. Physiol. Renal. Physiol. 290, F241-F250.

Goldschimdt, I., Grahammer, F., Warth, R., Schulz-Baldes, A., Garty, H., Greger, R., and Bleich, M. (2004). Kidney and colon electrolyte transport in CHIF knockout mice. Cell. Physiol. Biochem. 14, 113-120.
Hirata, T., Kaneko, T., Ono, T., Nakazato, T., Furukawa, N., Hasegawa, S., Wakabayashi, S., Shigekawa, M., Chang, M. H., Romero, M. F., and Hirose, S. (2003). Mechanism of acid adaptation of a fish living in a $\mathrm{pH}$ 3.5 lake. Am. J. Physiol. Regul. Integr. Comp. Physiol. 284, R1199-R1212.

Hirose, S., Kaneko, T., Naito, N., and Takei, Y. (2003). Molecular biology of major components of chloride cells. Comp. Biochem. Physiol. B Biochem. Mol. Biol. 136, 593-620.

Hoenderop, J. G., Nilius, B., and Bindels, R. J. (2005). Calcium absorption across epithelia. Physiol. Rev. 85, 373-422.

Horng, J. L., Lin, L. Y., Huang, C. J., Katoh, F., Kaneko, T., and Hwang, P. P. (2007). Knockdown of V-ATPase subunit A (atp6vla) impairs acid secretion and ion balance in zebrafish (Danio rerio). Am. J. Physiol. Regul. Integr. Comp. Physiol. 292, R2068-R2076.

Horng, J. L., Lin, L. Y., and Hwang, P. P. (2009). Functional regulation of $\mathrm{H}^{+}$-ATPase-rich cells in zebrafish embryos acclimated to an acidic environment. Am. J. Physiol. Cell Physiol. 296, C682-C692.

Hoshijima, K., and Hirose, S. (2007). Expression of endocrine genes in zebrafish larvae in response to environmental salinity. J. Endocrinol. 193, 481-491.

Hsiao, C. D., You, M. S., Guh, Y. J., Ma, M., Jiang, Y. J., and Hwang, P. P. (2007). A positive regulatory loop between foxi3a and foxi3b is essential for specification and differentiation of zebrafish epidermal ionocytes. PLoS ONE 2, e302. doi: 10.1371/journal. pone. 0000302 .

Hwang, P. P. (2009). Ion uptake and acid secretion in zebrafish (Danio rerio). J. Exp. Biol. 212, 1745-1752.

Jänicke, M., Carney, T. J., and Hammerschmidt, M. (2007). Foxi3 transcription factors and Notch signaling control the formation of skin ionocytes from epidermal precursors of the zebrafish embryo. Dev. Biol. 307, 258-271.

Jia, L. G., Donnet, C., Bogaev, R. C., Blatt, R. J., McKinney, C. E., Day, K. H., Berr, S. S., Jones, L. R., Moorman, J. R., Sweadner,K.J., and Tucker,A.L. (2005). Hypertrophy, increased ejection fraction, and reduced $\mathrm{Na}-\mathrm{K}$-ATPase activity in phospholemman-deficient mice. Am. J. Physiol. Heart Circ. Physiol. 288, H1982-H1988.

Jones, D. H., Li, T. Y., Arystarkhova, E., Barr, K. J., Wetzel, R. K., Peng, J., Markham, K., Sweadner, K. J., Fong, G. H., and Kidder, G. M. (2005). $\mathrm{Na}, \mathrm{K}$-ATPase from mice lacking the $\gamma$ subunit (FXYD2) exhibits altered $\mathrm{Na}^{+}$ affinity and decreased thermal stability. J. Biol. Chem. 280, 19003-19011.

Kirschner, L. B. (2004). The mechanism of sodium chloride uptake in hyperregulating aquatic animals. J. Exp. Biol. 207, 1439-1452.

Lansbery, K. L., Burcea, L. C., Mendenhall, M. L., and Mercer, R. W. (2006). Cytoplasmic targeting signals mediate delivery of phospholemman to the plasma membrane. Am. J. Physiol. Cell Physiol. 290, C1275-R1286.

Liao, B. K., Chen, R. D., and Hwang, P. P. (2009). Expression regulation of $\mathrm{Na}^{+}-\mathrm{K}^{+}$-ATPase $\alpha 1$-subunit subtypes in zebrafish gill ionocytes. Am. J. Physiol. Regul. Integr. Comp. Physiol. 296, R1897-R1906.

Liao, B. K., Deng, A. N., Chen, S. C., Chou, M. Y., and Hwang, P. P. (2007). Expression and water calcium dependence of calcium transporter isoforms in zebrafish gill mitochondrion-rich cells. BMC Genomics 8, 354. doi: 10.1186/1471-2164-8-354.

Lin, L. Y., Horng, J. L., Kunkel, J. G., and Hwang, P.P. (2006). Proton pump-rich cell secretes acid in skin of zebrafish larvae. Am. J. Physiol. Cell Physiol. 290, C371-C378.

Lin, T. Y., Liao, B. K., Horng, J. L., Yan, J. J., Hsiao, C. D., and Hwang, P. P. (2008). Carbonic anhydrase 2-like a and $15 \mathrm{a}$ are involved in acid-base regulation and $\mathrm{Na}^{+}$uptake in zebrafish $\mathrm{H}^{+}$-ATPase-rich cells. Am. J. Physiol. Cell Physiol. 294, C1250-R1260.

Mahmmoud,Y.A., Cramb, G., Maunsbach, A. B., Cutler, C. P., Meischke, L., and Cornelius, F. (2003). Regulation of Na,K-ATPase by PLMS, the phospholemman-like protein from shark: molecular cloning, sequence, expression, cellular distribution, and functional effects of PLMS. J. Biol. Chem. 278, 37427-37438.

Mahmmoud, Y. A., Vorum, H., and Cornelius, F. (2000). Identification of a phospholemman-like protein from shark rectal glands. Evidence for indirect regulation of $\mathrm{Na}, \mathrm{K}$-ATPase by protein kinase $\mathrm{c}$ via a novel member of the FXYDY family. J. Biol. Chem. 275, 35969-35977.

Marshall, W. S. (2002). $\mathrm{Na}^{+}, \mathrm{Cl}^{-}, \mathrm{Ca}^{2+}$ and $\mathrm{Zn}^{2+}$ transport by fish gills: retrospective review and prospective synthesis. J. Exp. Zool. 293, 264-283.

McCormick, S. D. (1990). Fluorescent labelling of $\mathrm{Na}^{+}, \mathrm{K}^{+}$-ATPase in intact cells by use of a fluorescent derivative of ouabain: salinity and teleost chloride cells. Cell Tissue Res. 260, 529-533.

Meij, I.C., Koenderink, J. B., van Bokhoven, H., Assink, K. F., Groenestege, W. T., de Pont, J. J., Bindels, R. J., Monnens, L. A., van den Heuvel, L. P., and Knoers, N.V. (2000). Dominant isolated renal magnesium loss is caused by misrouting of the $\mathrm{Na}^{+}, \mathrm{K}^{+}$-ATPase $\gamma$-subunit. Nat. Genet. 26, 265-266.

Mirza, M. A., Zhang, X. Q., Ahlers, B. A., Qureshi, A., Carl, L. L., Song, J., Tucker, A. L., Mounsey, J. P., Moorman, J. R., Rothblum, L. I., Zhang, T. S., and Cheung, J. Y. (2004). Effects of phospholemman downregulation on contractility and $\left[\mathrm{Ca}^{2+}\right]$ i transients in adult rat cardiac myocytes. Am J. Physiol. Heart Circ. Physiol. 286, H1322-H1330.

Miyamoto, K., Nakamura, N., Kashiwagi, M., Honda, S., Kato, A., Hasegawa, S., Takei, Y., and Hirose, S. (2002). RING finger, B-box, and coiledcoil (RBCC) protein expression in branchial epithelial cells of Japanese eel, Anguilla japonica. Eur. J. Biochem. 269, 6152-6161.

Nakada, T., Hoshijima, K., Esaki, M., Nagayoshi, S., Kawakami, K., and Hirose, S. (2007). Localization of ammonia transporter Rhcgl in mitochondrion-rich cells of yolk sac, gill, and kidney of zebrafish and its ionic strength-dependent expression. Am. J. Physiol. Regul. Integr. Comp. Physiol. 293, R1743-R1753.

Nakamura, N., Fukuda, H., Kato, A., and Hirose, S. (2005). MARCH-II is a syntaxin-6-binding protein involved in endosomal trafficking. Mol. Biol. Cell 16, 1696-1710.

Nakamura, N., and Hirose, S. (2008). Regulation of mitochondrial morphologyby USP30, a deubiquitinating enzyme present in the mitochondrial outer membrane. Mol. Biol. Cell 19, 1903-1911.

Nakamura, N., Suzuki, Y., Sakuta, H. Ookata, K., Kawahara, K., and Hirose, S. (1999). Inwardly rectifying $\mathrm{K}^{+}$channel Kir7.1 is highly expressed in thyroid follicular cells, intestinal epithelial cells and choroid plexus epithelial cells: implication for a functional coupling with $\mathrm{Na}^{+}, \mathrm{K}^{+}$-ATPase. Biochem. J. 342, 329-336.

Pan, T. C., Liao, B. K., Huang, C. J., Lin, L Y., and Hwang, P. P. (2005). Epithelial $\mathrm{Ca}^{2+}$ channel expression and $\mathrm{Ca}^{2+}$ uptake in developing zebrafish. Am. J. Physiol. Regul. Integr. Comp. Physiol. 289, R1202-R1211.

Perry, S. F., Shahsavarani, A., Georgalis, T., Bayaa, M., Furimsky, M., and Thomas, S. L. (2003). Channels, pumps, and exchangers in the gill and kidney of freshwater fishes: their role in ionic and acid-base regulation. J. Exp. Zool. A Comp. Exp. Biol. 300, 53-62.

Perry, S. F., Vulesevic, B., Grosell, M., and Bayaa, M. (2009). Evidence that SLC26 anion transporters mediate branchial chloride uptake in adult zebrafish (Danio rerio). Am. J. 
Physiol. Regul. Integr. Comp. Physiol. 297, R988-R997.

$\mathrm{Pu}, \mathrm{H}$. X., Cluzeaud, F., Goldshleger, R., Karlish, S. J., Farman, N., and Blostein, R. (2001). Functional role and immunocytochemical localization of the $\gamma \mathrm{a}$ and $\gamma \mathrm{b}$ forms of the $\mathrm{Na}, \mathrm{K}$ ATPase $\gamma$ subunit. J. Biol. Chem. 276, 20370-20378.

$\mathrm{Pu}, \mathrm{H}$. X., Scanzano, R., and Blostein, R. (2002). Distinct regulatory effects of the Na,K-ATPase $\gamma$ subunit. J. Biol. Chem. 277, 20270-20276.

Shinoda, T., Ogawa, H., Cornelius, F., and Toyoshima, C. (2009). Crystal structure of the sodium-potassium pump at $2.4 \AA$ resolution. Nature 459 , 446-450.

Söderberg, O., Leuchowius, K. J., Gullberg, M., Jarvius, M., Weibrecht, I., Larsson, L. G., and Landegren, U. (2008). Characterizing proteins and their interactions in cells and tissues using the in situ proximity ligation assay. Methods 45, 227-232.

Sweadner, K. J., and Rael, E. (2000). The FXYD gene family of small ion transport regulators or channels: cDNA sequence, protein signature sequence, and expression. Genomics 68, 41-56.

Therien, A. G., and Blostein, R. (2000). Mechanisms of sodium pump regulation. Am. J. Physiol. Cell Physiol. 279, C541-C566.

Tipsmark, C. K. (2008). Identification of FXYD protein genes in a teleost: tissue-specific expression and response to salinity change. Am. J. Physiol. Regul. Integr. Comp. Physiol. 294, R1367-R1378.

Tran, Y. H., Xu, Z., Kato, A., Mistry, A. C., Goya, Y., Taira, M., Brandt, S. J., and Hirose, S. (2006). Spliced isoforms of LIM-domain-binding protein (CLIM/ $\mathrm{NLI} / \mathrm{Ldb}$ ) lacking the LIM-interaction domain. J. Biochem. 140, 105-119.

Tseng, D. Y., Chou, M. Y., Tseng, Y. C., Hsiao, C. D., Huang, C. J., Kaneko, T., and Hwang, P. P. (2009). Effects of stanniocalcin 1 on calcium uptake in zebrafish (Danio rerio) embryo. Am. J. Physiol. Regul. Integr. Comp. Physiol. 296, R549-R557.

Wang, P. J., Lin, C. H., Hwang, H. H., and Lee, T.H. (2008). Branchial FXYD protein expression in response to salinity change and its interaction with $\mathrm{Na}^{+} /$ $\mathrm{K}^{+}$-ATPase of the euryhaline teleost Tetraodon nigroviridis. J. Exp. Biol. 211,3750-3758.

Wang, Y. F., Tseng, Y. C., Yan, J. J., Hiroi, J., and Hwang, P. P. (2009). Role of SLC12A10.2, a Na-Cl cotransporterlike protein, in a Cl uptake mechanism in zebrafish (Danio rerio). Am. J. Physiol. Regul. Integr. Comp. Physiol. 296, R1650-R1660.

Westerfield, M. (1995). The Zebrafish Book: A Guide to the Laboratory Use of Zebrafish (Danio rerio). Eugene, OR: University of Oregon Press.

Xu, Y., Wong, S. H., Tang, B. L., Subramaniam, V. N., Zhang, T., and Hong, W. (1998). A 29-kilodalton Golgi soluble $N$-ethylmaleimide-sensitive factor attachment protein receptor (Vti1-rp2) implicated in protein trafficking in the secretory pathway.J. Biol. Chem. 273, 21783-21789.

Yan,J.J.,Chou,M.Y., Kaneko, T., and Hwang, P. P. (2007). Gene expression of $\mathrm{Na}^{+} / \mathrm{H}^{+}$ exchanger in zebrafish $\mathrm{H}^{+}$-ATPase-rich cells during acclimation to low- $\mathrm{Na}^{+}$and acidic environments. Am. J. Physiol. Cell Physiol. 293, C1814-C1823.

Yoon, Y., Pitts, K. R., Dahan, S., and McNiven, M. A. (1998). A novel dynamin-like protein associates with cytoplasmic vesicles and tubules of the endoplasmic reticulum in mammalian cells. J. Cell Biol. 140, 779-793.

Zhang, X. Q., Qureshi, A., Song, J., Carl, L. L., Tian, Q., Stahl, R. C., Carey, D. J., Rothblum, L. I., and Cheung, J. Y. (2003). Phospholemman modulates $\mathrm{Na}^{+} / \mathrm{Ca}^{2+}$ exchange in adult rat cardiac myocytes. Am. J. Physiol. Heart Circ. Physiol. 284, H225-H233.

Conflict of Interest Statement: The authors declare that the research was conducted in the absence of any commercial or financial relationships that could be construed as a potential conflict of interest.

Received: 08 March 2010; paper pending published: 02 April 2010; accepted: 07 August 2010; published online: 23 August 2010.

Citation: Saito K, Nakamura N, Ito $Y$, Hoshijima K, Esaki M, Zhao B and Hirose S (2010) Identification of zebrafish Fxyd1 1 a protein that is highly expressed in ion-transporting epithelium of the gill and skin and its possible role in ion homeostasis. Front. Physio. 1:129. doi: 10.3389/ fphys.2010.00129

This article was submitted to Frontiers in Aquatic Physiology, a specialty of Frontiers in Physiology.

Copyright $\odot 2010$ Saito, Nakamura, Ito, Hoshijima, Esaki, Zhao and Hirose. This is an open-access article subject to an exclusive license agreement between the authors and the Frontiers Research Foundation, which permits unrestricted use, distribution, and reproduction in any medium, provided the original authors and source are credited. 


\section{SUPPLEMENTARY MATERIAL}

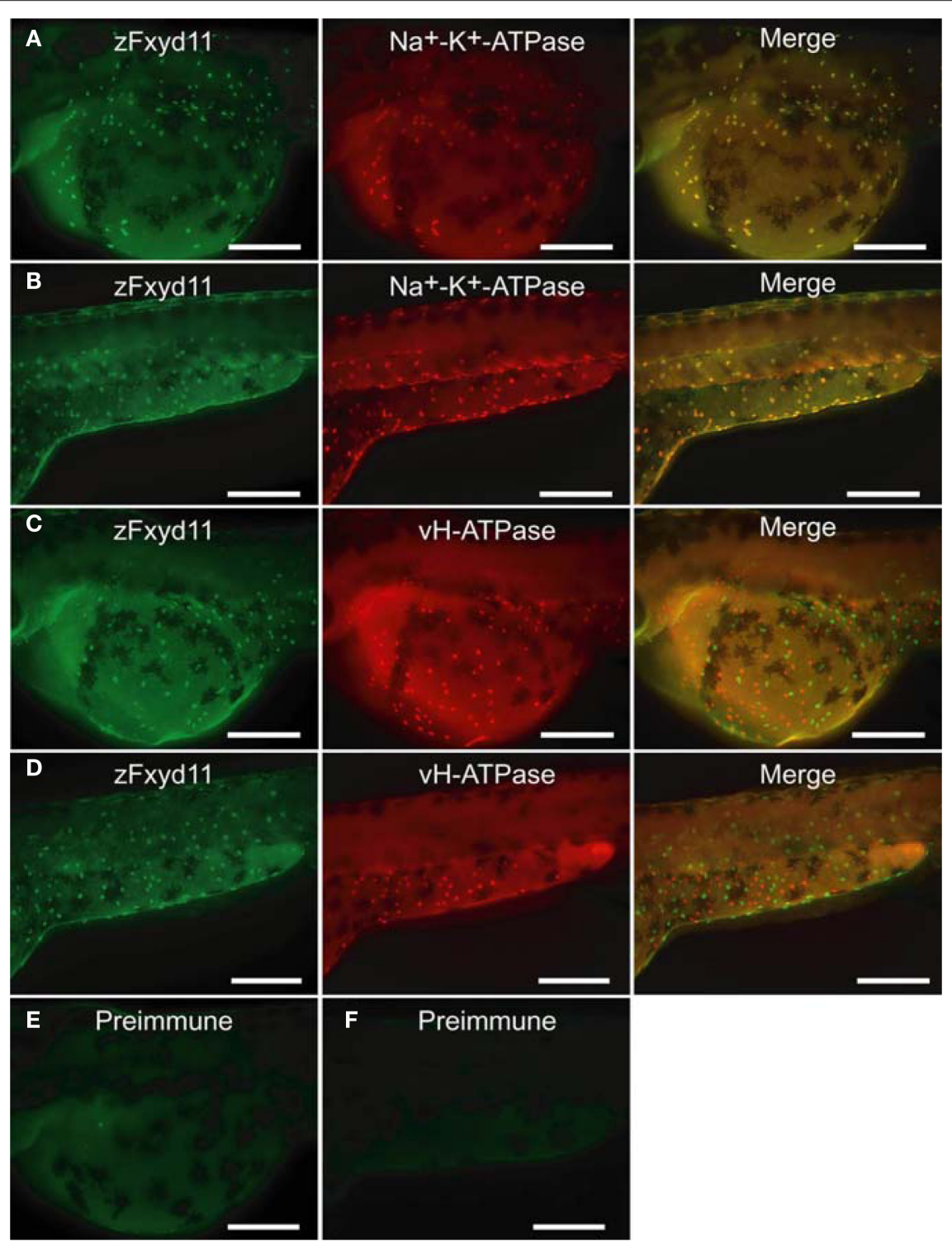

FIGURE S1 | Localization of zFxyd11 in NaK-MRCs of the skin of zebrafish larvae. Immunofluorescence staining was performed on 2-dpf zebrafish larvae with anti-zFxyd11 antiserum [green in (A-D)], along with anti-Na+- $\mathrm{K}^{+}-\mathrm{ATPase}$ [red in (A), (B)] or anti-vH+-ATPase antiserum [red in (C), (D)]. Control staining was carried out with preimmune serum $\mathbf{( E , F )}$. Regions of the yolk sac $(\mathbf{A}, \mathbf{C}, \mathbf{E})$ and the yolk sac extension and the trunk $(\mathbf{B}, \mathbf{D}, \mathbf{F})$ are shown. Note that signals for zFxyd11 entirely overlap with NaK-MRCs on the skin of yolk, yolk extension, and trunk (A,B), and are not colocalized with vH-MRCs (C,D). Scale bars, $200 \mu \mathrm{m}$. 